\title{
An integrated platform for bovine DNA methylome analysis suitable for small samples
}

\author{
Habib A Shojaei Saadi ${ }^{1}$, Alan M O’Doherty ${ }^{2}$, Dominic Gagné ${ }^{\text {, Éric Fournier }}{ }^{1}$, Jason R Grant ${ }^{3}$, \\ Marc-André Sirard ${ }^{1}$ and Claude Robert ${ }^{1 *}$
}

\begin{abstract}
Background: Oocytes and early embryos contain minute amounts of DNA, RNA and proteins, making the study of early mammalian development highly challenging. The study of the embryo epigenome, in particular the DNA methylome, has been made accessible thanks to the possibility of amplifying specific sequences according to their initial methylation status. This paper describes a novel platform dedicated to the genome-wide study of bovine DNA methylation, including a complete pipeline for data analysis and visualization. The platform allows processing and integrating of DNA methylome and transcriptome data from the same sample. Procedures were optimized for genome-wide analysis of $10 \mathrm{ng}$ of DNA (10 bovine blastocysts). Bovine sperm and blastocysts were compared as a test of platform capability.

Results: The hypermethylation of bovine sperm DNA compared to the embryo genome was confirmed.

Differentially methylated regions were distributed across various classes of bovine sperm genomic feature including primarily promoter, intronic and exonic regions, non-CpG-island regions (shore, shelf and open-sea) and CpG islands with low-to-intermediate CpG density. The blastocyst genome bore more methylation marks than sperm DNA only in CpG islands with high CpG density. Long-terminal-repeat retrotransposons (LTR), LINE and SINE were more methylated in sperm DNA, as were low-complexity repetitive elements in blastocysts.
\end{abstract}

Conclusions: This is the first early embryo compatible genome-wide epigenetics platform for bovine. Such platforms should improve the study of the potential epigenetic risks of assisted reproductive technologies (ART), the establishment sequence of embryonic cell lines and potential deviations in both gene expression and DNA methylation capable of having long-term impact.

Keywords: Epigenome, DNA methylation, Bovine embryo, Methylome and transcriptome parallel analysis, Analysis pipeline, CpG enrichment, Repetitive elements, Epigenome-wide association study

\section{Background}

The study of early embryonic development continues to pose formidable technical challenges due in large part to the limited amounts of sample material. However, highthroughput high-fidelity amplification of nucleic acid is making the macromolecular study of embryonic physiology more accessible. Microarray platforms, and more recently RNAseq, have made studying the early embryo transcriptome almost routine. Our group has been developing

\footnotetext{
* Correspondence: claude.robert@fsaa.ulaval.ca

'Laboratory of Functional Genomics of Early Embryonic Development,

Institut des nutraceutiques et des aliments fonctionnels, Faculté des sciences de l'agriculture et de l'alimentation, Pavillon des services, Université Laval,

Québec GIV 0A6, Canada

Full list of author information is available at the end of the article
}

bovine and porcine microarrays based on transcriptomic platforms that include standardized sample preparation procedures and a complete user-friendly software suite for data normalization and analysis, allowing efficient processing of samples from extraction through to the generation of publishable graphs [1,2]. Transcriptomic platforms have been used to study how early embryos of many different species interact with their immediate microenvironment [3-8]. Although very useful, the transcriptome has not allowed us to determine whether or not deviant gene expression, that is observed in embryos, is a transient adaptation to surrounding conditions that later yields to normal expression without any long-term impact on development. In order to provide a more complete picture of embryo adaptation and its potential long-term consequences, study 
of the epigenome is necessary $[9,10]$. The epigenome is the sum of all epigenetic information [11] and refers more precisely to the complete description of chemical changes to DNA and histones [12], including histone tail modifications, chromatin remodelling proteins, and ncRNA. Epigenomics and transcriptomics are closely interrelated in terms of gene function and regulation $[13,14]$ and together modulate gene expression.

Among epigenomic effectors, DNA methylation is believed to be a strong primary molecular mark having a major impact on intergenerational gene silencing $[15,16]$. DNA methylation patterns are known to be relatively stable and established in a tissue-specific manner $[17,18]$. However, following fertilization and during mammalian preimplantation development, the DNA methylation pattern is dynamic and undergoes reprogramming in the form of a wave of genome-wide de-methylation and re-methylation [19-24], thus putting the embryo at risk of programming errors [25]. Furthermore, the study of how the DNA methylome can be modified by changes in the embryo microenvironment such as in vivo/vitro culture, uterine conditions, or maternal nutritional regimen has represented a major challenge and continues to do so, due mainly to sample scarcity offering input DNA well below minimal recommendations.

Numerous platforms already exist to study methylation of targeted loci or to obtain genome-wide methylation profiles. For the study of very small samples, determining DNA methylation at targeted loci has so far been more successful than genome-wide approaches [26]. The main advantages of general survey are the possibility of describing physiological responses at the genome-wide scale and the potential for novel discovery.

The aim of the present work was to develop a technological platform that is complementary to existing platforms, in order to provide a whole-genome view of DNA methylation in bovine early embryos. Since a diploid mammalian nucleus contains about 6.8 picograms of DNA (www.genomesize.com) and the expanded blastocyst of large mammalian species is composed of about 150 cells, a single bovine blastocyst contains approximately $1 \mathrm{ng}$ of DNA. The current benchmark for minimal sample size is around $10 \mathrm{ng}$, therefore corresponding to a pool of 10 expanded blastocysts. The other criterion is ease of use, at both the sample handling and data processing steps. We thus sought to identify an existing methodological approach which would be best suited to analyze very small samples of DNA. The platform was tested and validated using experimental samples.

\section{Results}

\section{Platform design}

The EmbryoGENE (http://embryogene.ca) DNA Methylation Analysis (EDMA) platform was designed for high-throughput methylation profiling of bovine genome using limited amounts of input material. It combines four independent methodological principles: i) restriction endonucleasebased (RE) (MseI) genomic DNA fragmentation; ii) targeting methylated regions using a cocktail of methyl-sensitive restriction endonucleases; iii) amplification of methylated (thus protected) fragments using ligation-mediated PCR; and iv) identification of the amplified methylated fragments using a microarray. The EDMA workflow is presented in Figure 1.

Sample treatment protocol and microarray design were optimized in parallel. Our laboratory has previously conducted a survey of DNA methylation in bovine embryos using various reduced representation approaches [27]. This allowed us to identify a collection of loci at which DNA methylation varies in association with early development. These loci included CpG islands, gene bodies, intergenic regions and repetitive elements. The oligo design accounted for the sample preparation steps in which genomic DNA was fragmented using the MseI restriction enzyme, which recognizes 5 '-T/TAA-3, thus avoiding methylated cytosine residues. In silico digestion of the bovine genome shows that MseI yields fragments averaging $160 \mathrm{bp}$ in length (see Additional file 1: Figure S1 A). A second layer of in silico analysis located the methyl-sensitive restriction endonucleases (MSRE) restriction sites, namely C/CGG (HpaII), GC/ GC (HinP1I) and C/CGC (Aci1I). Distribution of common and unique MSRE sites within MseI fragments is shown in Additional file 1: Figure S1 B. Furthermore, the information regarding the number of $\mathrm{CpG}$ sites per restriction fragments and the number of MSREs restriction sites per restriction fragments are provided in Additional file 1: Figure S2 A-D. The 60-mer oligo design was based, in part, on a collection of MseI fragments containing MSRE sites within the genomic loci that we previously found to bear methylation or hydroxymethylation marks in early bovine embryos [27], to which were added CpG islands determined by in silico analysis. Additional oligos were designed by tiling the MseI fragments adjacent to this initial set of targets until the capacity of a single microarray slide was reached $(1 \times 1$ $\mathrm{M}$ oligos). Preliminary hybridizations allowed selection of a subset of $400 \mathrm{~K}$ oligos that performed well, based on sequence specificity and signal strength variations across the set of test hybridizations (data not shown). The final probe collection queries a variety of different genomic features not limited to CpG islands. A summary of the genomic targets surveyed by the microarray is shown in Figure 2 and Additional file 2: Table S2-4. As illustrated for two bovine imprinted genes (NNAT, PEG10) in Figure 3, the EDMA probes were distributed across various genomic features (intergenic, promoters, gene body, and repetitive elements).

Since the platform uses a cocktail of MSREs to target genomic locations bearing methylation marks, the extent of cleavage is a critical factor. Incomplete cleavage will 


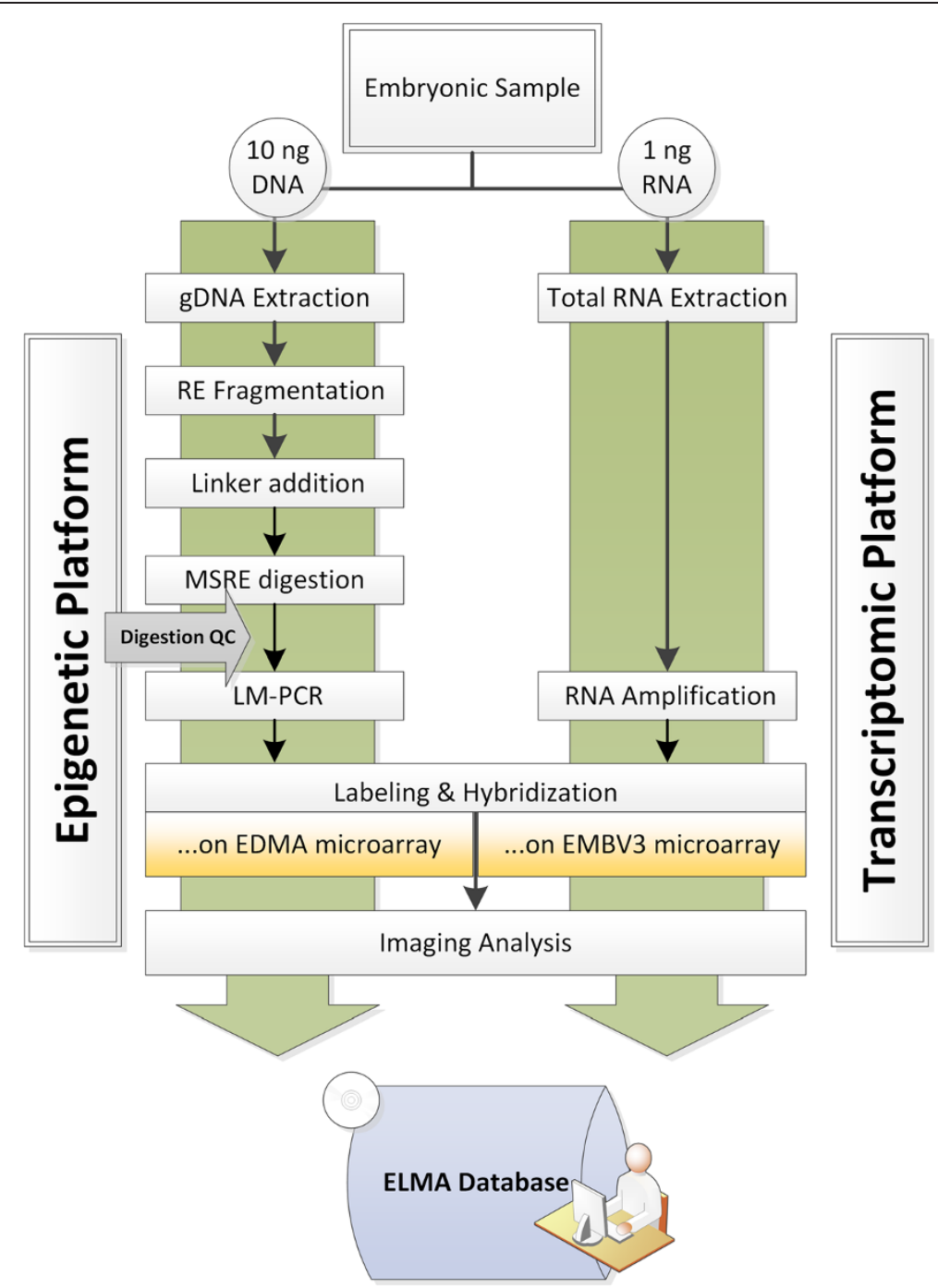

Figure 1 Sequence of steps involved in the generation of methylome and transcriptome data from the same sample using EDMA platform. A quality control step prior to LM-PCR allows evaluation of the efficiency of cleavage by MSREs for methylome analysis. EDMA: EmbryoGENE DNA methylation analysis platform, ELMA: EmbryoGENE LIMS and Microarray Analysis, EMBV3: EmbryoGENE bovine transcriptomics microarray Version 3, LM-PCR: Ligation-mediated PCR, MSRE: Methyl-sensitive restriction endonuclease, RE: Restriction endonuclease (Msel).

lead to false positive results. For quality control purposes, control DNA templates were designed to account for extent of cleavage both by MseI and the MSREs cocktail. A pair of DNA templates was designed for each MSRE (Figure 4A). All spiked-in controls had internal MseI sites at their ends, and for each pair, one template was methylated in vitro for protection against MSRE activity. The controls were thus subjected to the same cleavage conditions as the sample. Following genomic fragmentation, adaptor ligation and MSRE treatment, sample quality was determined using qPCR, with calculation of the extent of cleavage for each MSRE. The difference in threshold cycle $\left(C_{t}\right)$ between protected (hypermethylated) and unprotected (hypo/unmethylated) control templates can be calculated, while sample uniformity can be visualized from the amplification curves (Figure 4B, 4C). Only samples displaying uniformity with the other samples cleaved $>97 \%$ in the same cohort were retained for downstream treatment. Insufficiently cleaved samples were in some cases subjected to a second treatment with additional MSRE digestion.

In EDMA platform, after hybridization on the microarray and data analysis there are two types of quality control (QC) plots which the examples are shown in Figure 5. The first plot, which assesses the completeness of the genomic digestion, shows nearly complete cleavage by MseI, with most control probes showing signal below the background noise (Figure 5A). The second quality control assess the quality of detected signals. The plot uses signals from probes corresponding to the spiked-in controls, and confirms that unprotected 


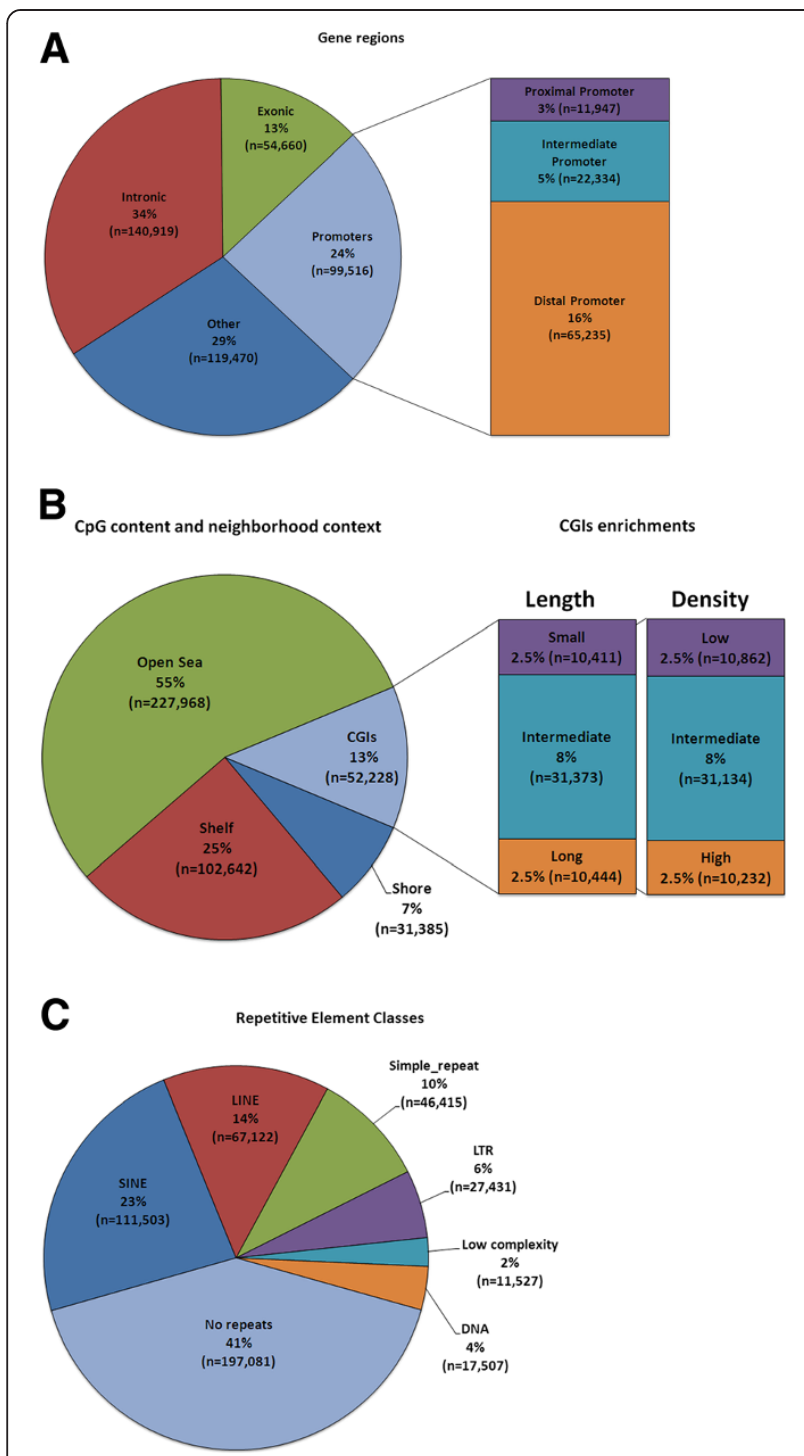

Figure 2 The characteristics of EDMA array. (A) Gene region coverage by the probes. The single greatest proportion (34\%) corresponds to intronic regions. (B) Probe distribution based on proximity to $\mathrm{CpG}$ islands as well as $\mathrm{CpG}$ islands-related enrichments. More than half of the probes target fragments in the open-sea region. (C) Proportions of different classes of bovine repetitive elements detectable by the EDMA platform.

templates led to low signals and vice versa for protected fragments (Figure 5B).

\section{The analysis pipeline}

For each dye-swaps microarray hybridization, the quantification of methylation measurements are based on $M$ values (the log differential- expression ratio of the two channels) which further normalized (inter \& intra-array) and statistical analysis is performed as described in methods. This means larger values represented more evidence of relative methylation similar to other microarray-based genome- wide DNA methylation analysis platforms [28]. To support data mining, an extensive analysis pipeline was designed with the goal to sort the data according to defined structural characteristics (e.g. near known genes, within gene body components, distance from $\mathrm{CpG}$ islands, etc.). We designed a user-friendly and comprehensive bioinformatics data analysis pipeline to complement our developed platform (EDMA). A complete schematic of our data analysis pipeline is shown in Figure 6. The data analysis pipeline was designed to be compatible with results obtaining from our array-based gene expression platform [1]. It enables to identify alterations of DNA methylation in bovine genomic regions under various enrichment outputs in parallel to deviations in transcription. The pipeline comprises several analysis steps for data QC and differential analysis, generating a list of DMRs as well as downstream sequence-based enrichment analyses, Hot spot detection and concordant analysis in search of loci where both transcriptomic and DNA methylation are affected. The information is binned according to the set of annotations given to every genomic locus (see methods for details). Typical enrichment analysis account for CpG islands neighbourhood both in length and density, gene body structures (promoter, exons, introns) and classes of bovine repetitive elements (low complexity, SINE or LINE elements). Since EDMA is not based on bisulfite conversion and sequencing, it does not provide a relative value of the extent of DNA methylation. This information needs to be determined by targeted pyrosequening of the regions of interest.

The data analysis pipeline output is a large contingent of plots that serve five different objectives (Figure 7): i) to document the quality of the samples through the quality control plots ; ii) to provide visual aid to determine where the MSRE-protected fragments were found for each sample type; iii) to provide an overall perspective of the extent of the differences in methylation between the samples; iv) to mine differentially methylated regions (DMRs) data according to genomic features; v) and lastly, the Circos plot which can be used to integrate the epigenomic and transcriptomic data (or present a chromosomal overview of either type alone).

\section{DNA methylation profiles of bovine sperm and early embryos}

- Genome-wide overview of DNA methylation profiles.

Platform performance was evaluated on the basis of the contrast in genomic DNA methylation patterns between bovine sperm and blastocysts. Similar amounts of input DNA from both sample types were processed, and microarray data was analyzed using the pipeline described above. Using a predetermined significance criterion i.e. 


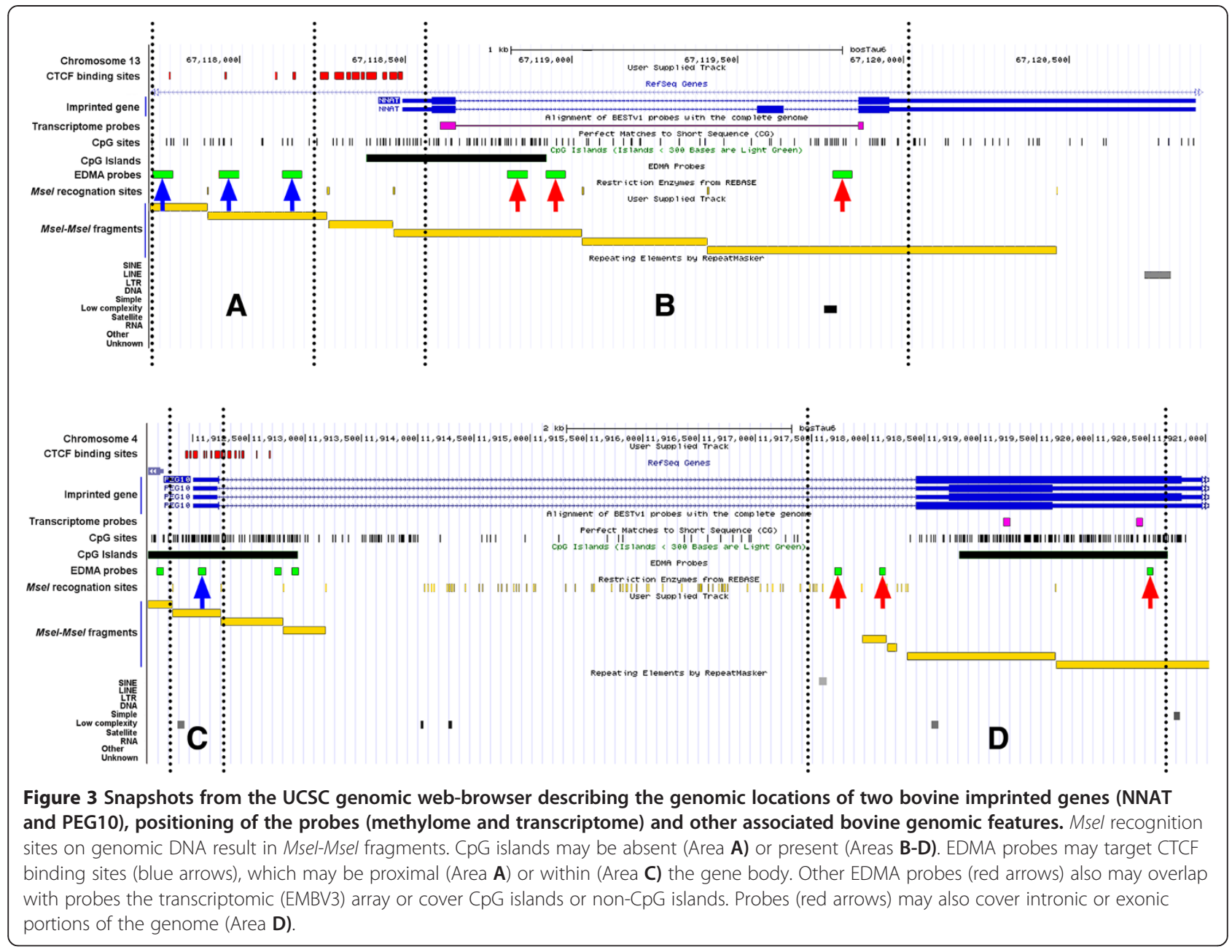

Fold-change $>2^{\wedge} 1.5$, p-value $<0.05,811$ DMRs were identified, most of which $(>85 \%)$ were due to hypermethylation in sperm (Figure 8). Large numbers of the methylated loci found in the embryo genome were also found in sperm DNA. Differences can also be observed using the genome-wide view provided by Circos plot, which shows a prevalence of hypomethylation in the sperm for chromosome X compared to blastocysts DNA. Nearly all (97\%) of the top 100 identified differentially methylated regions (DMRs) were found to be hypermethylated in sperm DNA (Figure 9). This reveals that the majority of DMR genes in bovine sperm DNA lose their methylation after fertilization and during early embryo development, at least until the blastocyst stage.

- Characteristics of differentially methylated regions (DMRs).

Our data revealed that sperm DNA shows a tendency to hypermethylation compared to blastocysts in all types of promoter, intronic and exonic regions, non-CpG islands regions (shore, shelf and open sea) and CpG islands with low-to-intermediate $\mathrm{CpG}$ density and smallto-intermediate length (Figure 10). Only in high-density CpG islands in the blastocyst genome demonstrated a tendency to hypermethylation compared to sperm. Amongst DMRs containing repetitive elements, bovine sperm DNA tended to be hypermethylated in the majority of the repetitive element classes, in particular long-terminal-repeat (LTR) retrotransposons, LINE and SINE. However, lowcomplexity repetitive elements showed more hypermethylated in the blastocyst genome.

\section{DMR validation}

Seven candidate DMR loci from different regions of the bovine genome were selected and primers were designed (see Additional file 2: Table S5) for measurement of DNA methylation levels by pyrosequencing. These results confirmed those obtained using our platform and showed very high levels of methylation with high reproducibility in sperm DNA compared to the blastocyst genome (Figure 11). However, as expected there was not any linear correlation between the EDMA fold changes for the selected DMRs and their corresponding measured 

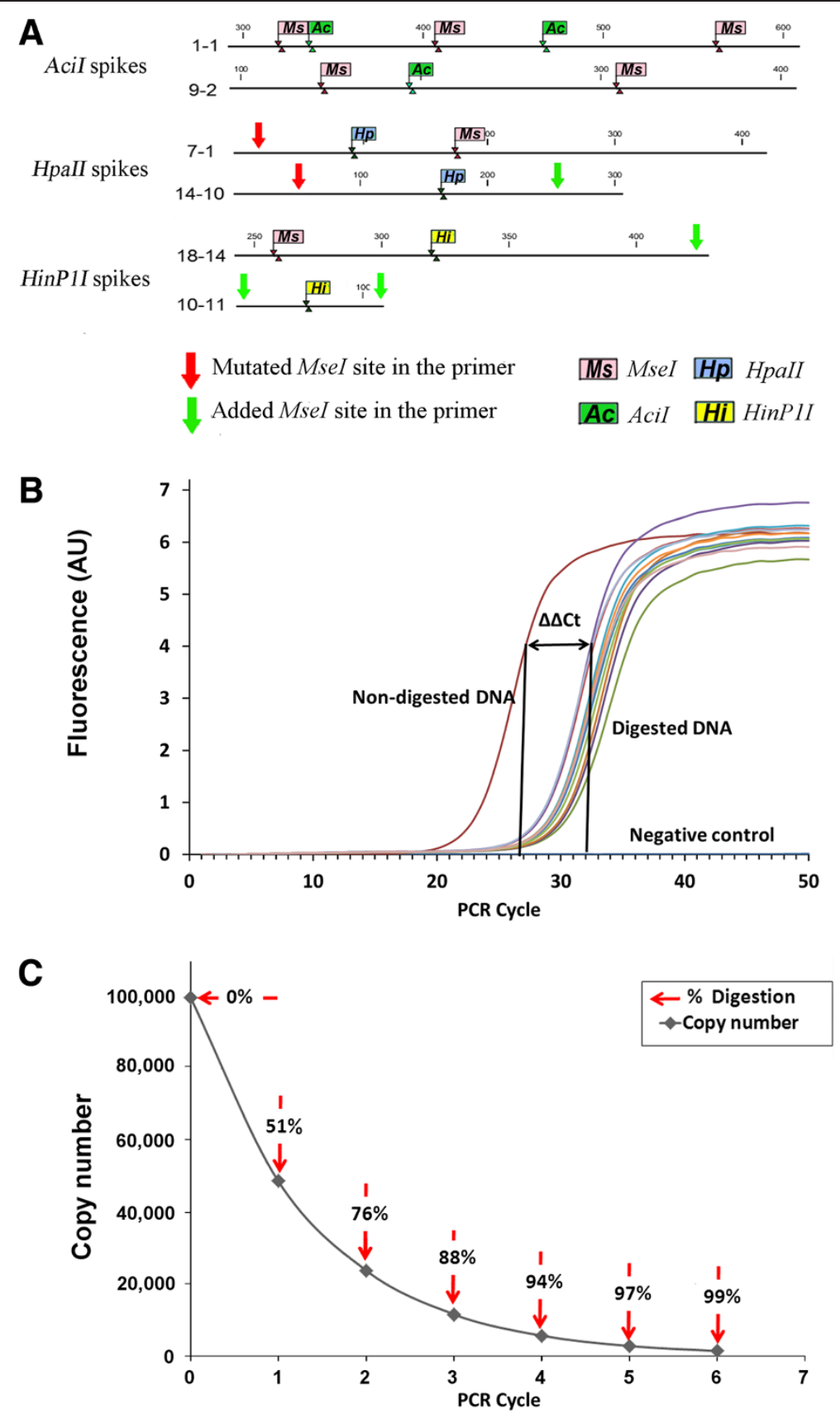

Figure 4 The feature of EDMA spiked-in controls and the quality control process of MSREs digestion assessment. (A) Location of sites cleaved by endonucleases within exogeous control DNA. (B) Difference in PCR threshold cycle ( $\Delta \Delta \mathrm{Ct}$ ) between un-cleaved (positive control) and cleaved samples. (C) Plot of residual number of copies and corresponding efficiency of cleavage by MSRE versus PCR cycle number, indicating that satisfactory cleavage $(97 \%)$ is reached at the end of five PCR cycles.

fold changes after the pyrosequencing confirmation (see Additional file 1: Figure S3).

\section{Discussion}

\section{Development of EDMA}

The study of the epigenome has become a prime focus in the effort to understand the expression of complex phenotypes such as obesity, diabetes [29,30], mental disorders
[31,32] and cancers [33-36]. Vast epigenetic erasure and reprogramming events during early embryogenesis make this phase of development a window for perturbations, potentially having long-term impact on phenotype in adulthood. Methods for monitoring candidate loci using as little as single cell [37], one oocyte [38] or single cell blastomere [39] have been developed. The aim of the present work is to develop a robust technological platform to study 

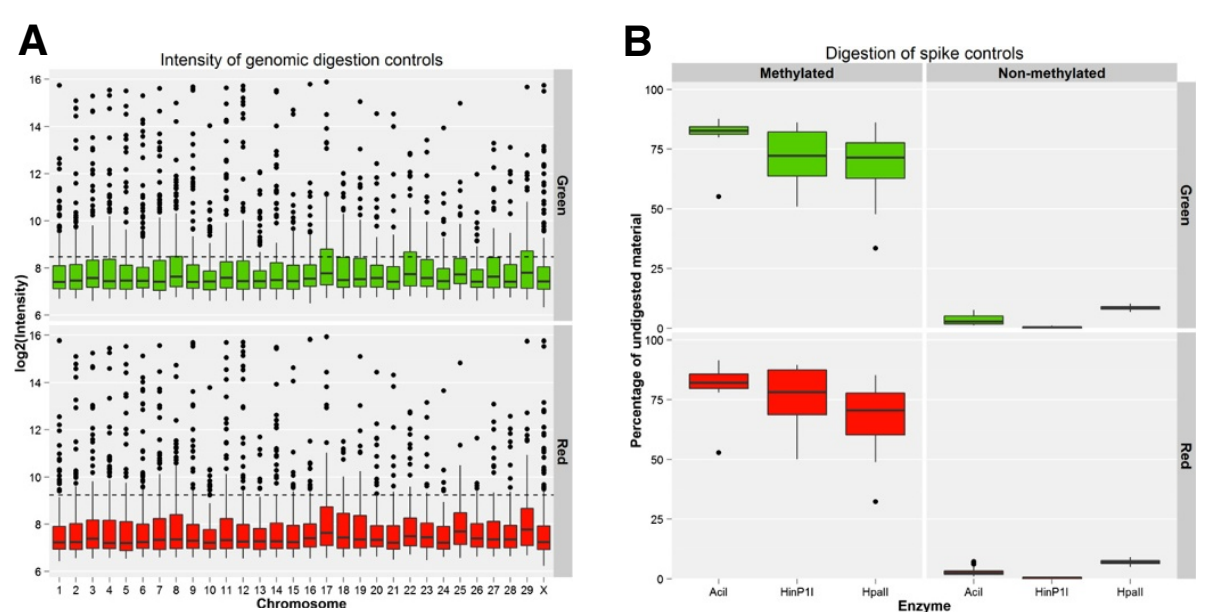

Figure 5 The two types of quality control (QC) plots generating after EDMA microarray hybridization and data analysis. (A) Signal intensity of control probes designed to overlap an Msel site. Probes corresponded to loci distributed throughout the bovine genome. The dashed horizontal line represents the limit of detection (mean intensity of negative controls plus four standard deviations). Intensities below this line indicate successful genomic fragmentation by Msel. (B) Cleavage of synthetic spiked-in control DNA pairs by MSRE, based on microarray signal. Signals from unprotected (unmethylated) fragments (right) are near background values.

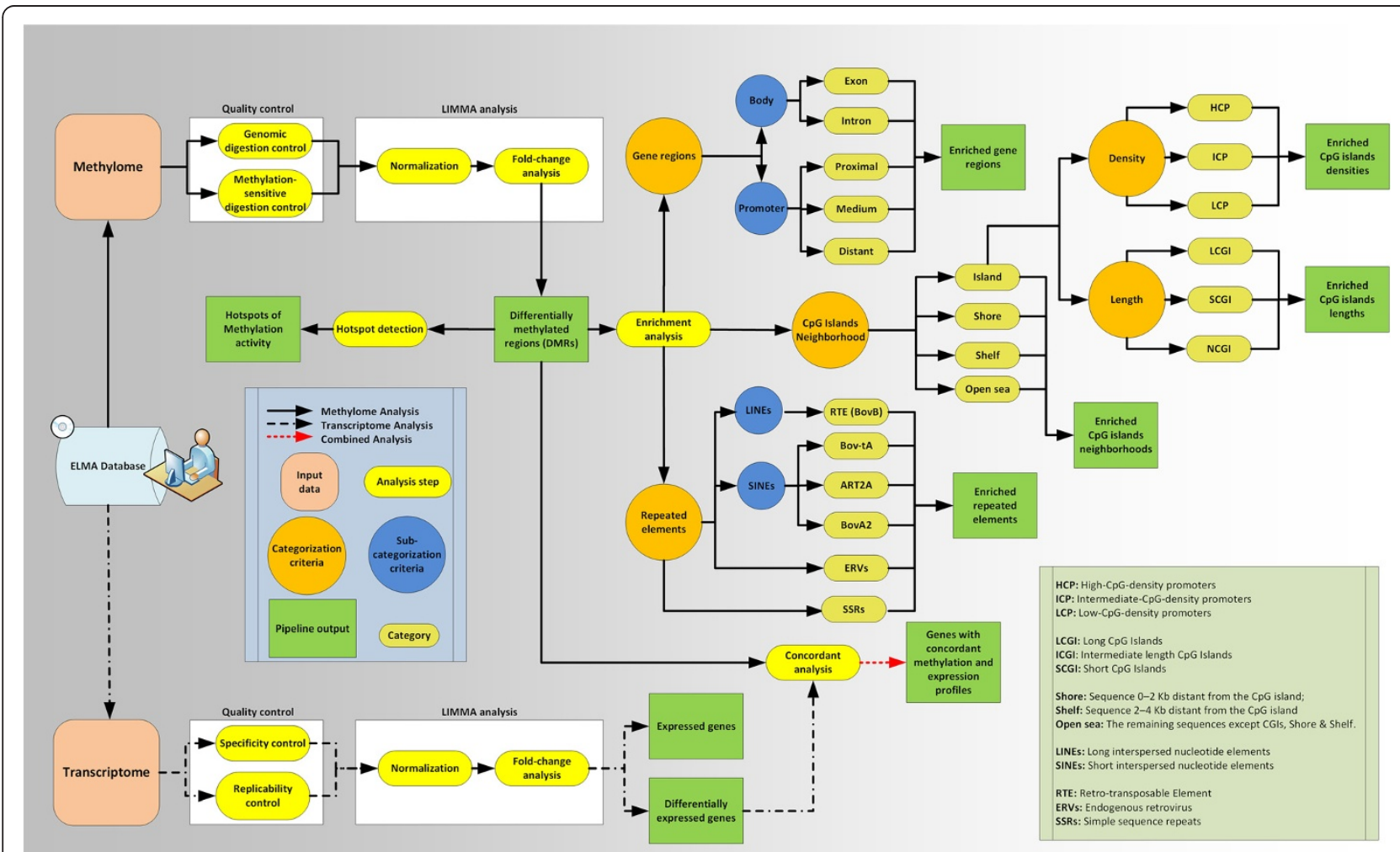

Figure 6 The EDMA DNA methylation analysis pipeline. This genome-wide methylome analysis pipeline was designed to provide a comprehensive set of plots to ease interpretation of both methylome and transcriptome raw data generated from the same sample. Information is binned according to known functions or genetic features. 


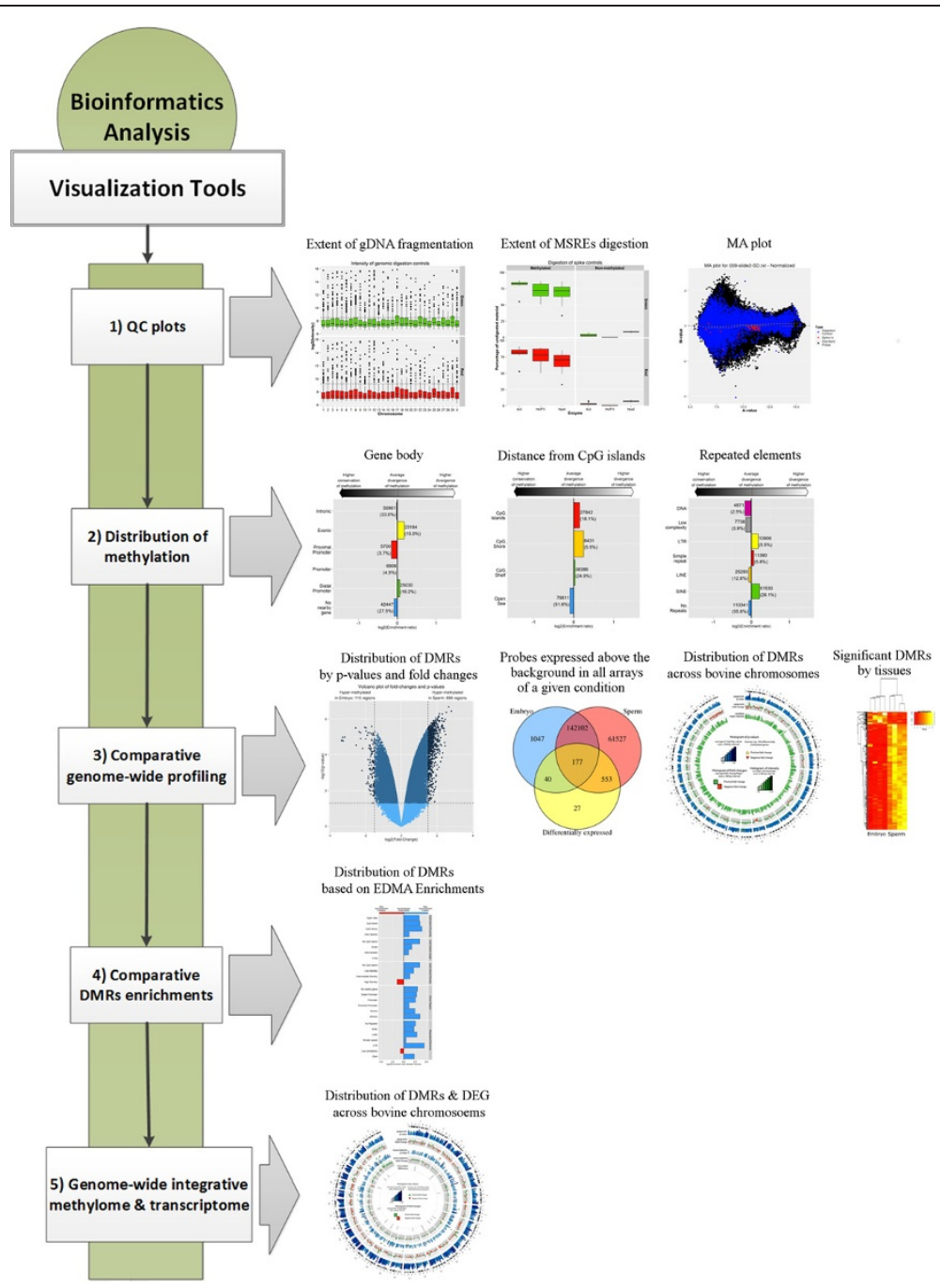

Figure 7 List of the graphs generated by EDMA analytical pipeline.

genome-wide DNA methylation, suitable for the small amount of sample material obtainable from early embryos and to complement this platform with a comprehensive suite of tools for quality control and data analysis. The EmbryoGENE DNA methylation analysis (EDMA) platform was developed for compatibility with our previously published transcriptome analysis platform [1] with the aim of integrating data of both types from the same sample.

Among the three sample treatment options currently employed to study genomic DNA methylation [26], we opted for methyl-sensitive restriction enzymes (MSREs) over bisulfite conversion and affinity selection because it allowed for robust processing of DNA input of a few nanograms as well as a more straightforward data processing based on the well-established tools dedicated to microarray data analysis. An optimal procedure was sought for isolating intact genomic DNA for subsequent specific fragmentation by nucleases, which offers better repeatability than mechanical shearing (data not shown). The selection of methylated fragments thus obtained is performed by means of successive PCR reactions, while amplicon identification is achieved using a microarray, which brings the added benefit of mature data processing and analysis procedures. In addition, each microarray slide is composed of two arrays that hold two samples each (two-color arrays), allowing for the necessary inclusion of biological replicates in the experimental design. All platforms must include biological replication, since the extent of DNA methylation is naturally variable among samples of similar origin.

The procedures involved in EDMA, namely restriction endonuclease genomic fragmentation, adaptor ligation, cleavage by MSREs, selection of protected fragments by PCR and identification of fragments by microarray, are essentially those proposed for nanoHELP and for arraycomparative genomic hybridization, which have been 


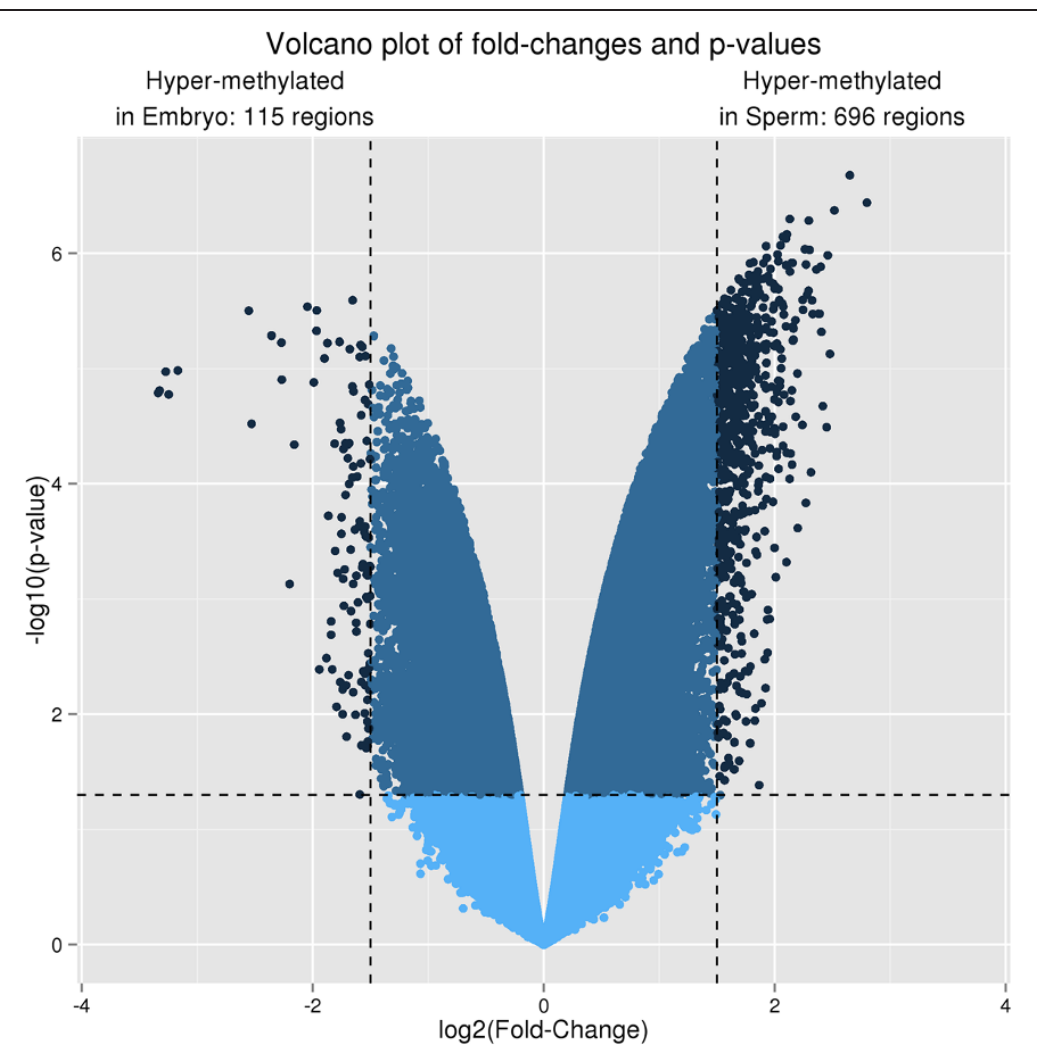

Figure 8 Volcano plot of genome-wide DNA methylation. This plot shows clearly that bovine sperm DNA was more methylated than embryo DNA.

applied successfully to inputs of respectively $10 \mathrm{ng}$ and a single cell [40]. Ten nanograms is the approximate quantity of DNA obtainable from 10 expanded blastocysts. Comparing $1 \mu \mathrm{g}$ and $10 \mathrm{ng}$ genomic DNA input, Oda and colleagues demonstrated that the smaller input provided higher reproducibility $(R>0.96)$, due probably to more complete cleavage, suggesting that low input of genomic DNA would likely be more suitable for MSREbased platforms [41]. Sample processing used in EDMA was tested with lower gDNA inputs as low as 15 cells and genomic coverage was measured using the $50 \mathrm{~K}$ bovine SNP Chip which showed important loss of information due to allele drop-out when input were lower than $1 \mathrm{ng}$ (data not shown). When dealing with single cell DNA methylation analysis, partial sample loss is often observed. This loss may not be problematic when aiming for targeted loci but is definitely problematic for genomewide profiling. As such, $10 \mathrm{ng}$ was set the minimal input leading to a robust DNA methylation profiling.

In order to prevent the introduction of false positives that would arise from incomplete cleavage of sample DNA $[42,43]$, spiked-in controls were designed to account for extent of cleavage both during the initial MseI fragmentation and by MSREs. Samples were tested before fragment amplification by PCR to ensure that cleavage was sufficient. When cleavage is incomplete, the MSREs treatment can be repeated. For each MSRE, a pair of synthetic DNA controls was designed, one of which was methylated in vitro and used as a control for fragment protection, while the unprotected counterpart acted as the cleavage target.

One of the main concerns with any genome-wide approach is the actual genomic coverage. Since the MseI recognition site is T/TAA, CpG dinucleotides are left intact and most $\mathrm{CpG}$ islands are conserved [44]. These sites are very abundant throughout the genome, resulting in small fragments well suited for LM-PCR $[40,45,46]$. By fragmenting the entire genome in this manner, methylation status outside $\mathrm{CpG}$ islands can be queried. This provides valuable information, since evidence is mounting for potential important roles for $5 \mathrm{mC}$ in non-CpG islands, which have been found more dynamic than CpG islands with respect to methylation-based regulation [47]. This is potentially even more important in early embryos where overall demethylation just occurred.

Since detection based on restriction enzymes is limited to fragments bearing the recognition sites $[11,48]$, adequate genomic coverage by MSRE requires a combination of nucleases $[27,44]$. In silico analysis showed that compared to HpaII alone, the combination of HpaII, HinP1I and AcilI increased the coverage of CpGs sites in the probes designed for EDMA from $2.3 \%$ to $8.6 \%$ and genomic coverage from $4.8 \%$ to $6.1 \%$ (see Additional 


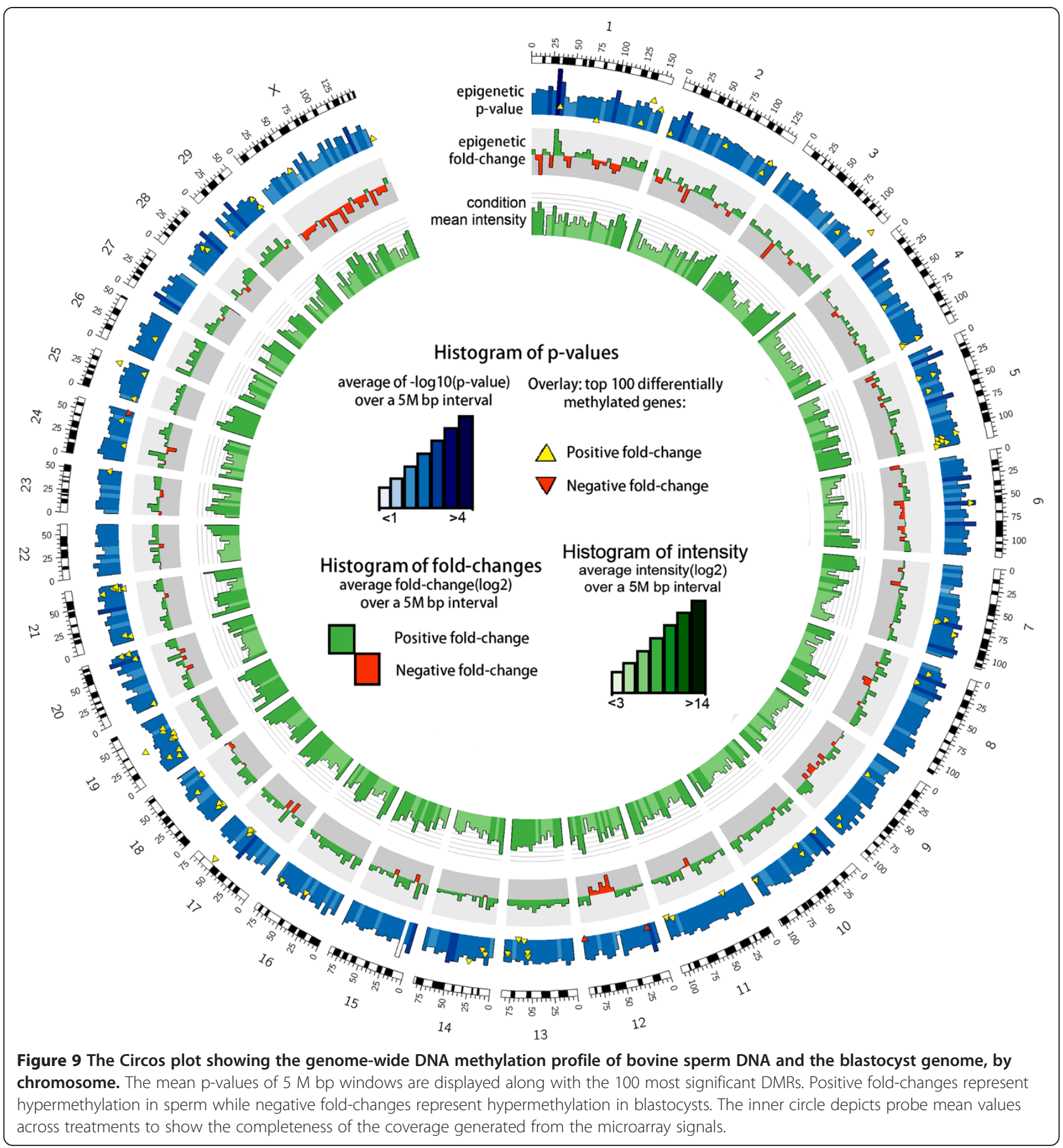

file 2: Table S2). This coverage accounts for a little more than 2.3 M CpG sites, which corresponds to about 10\% of all $\mathrm{CpG}$ sites in the bovine genome. Similar coverage is obtained using reduced-representation bisulfite sequencing (RRBS), which has been shown to be efficient with small DNA input $[19,49,50]$. Both EDMA and RRBS have several steps in common, including genomic fragmentation by restriction enzyme, adaptor ligation and PCR amplification. The main benefits of reduced-representation bisulfite sequencing are that it allows quantitative evaluation of methylation at single-base resolution and is applicable to all species since it is based on DNA sequencing, which does not require a priori knowledge of the genome [51]. However, EDMA similar to any other MSREs enrichment-based approaches generate a list of DMRs ranked in order of significance but does not provide information regarding the extent of DNA methylation which must be determined by targeted pyrosequencing. Furthermore, enrichment-based 


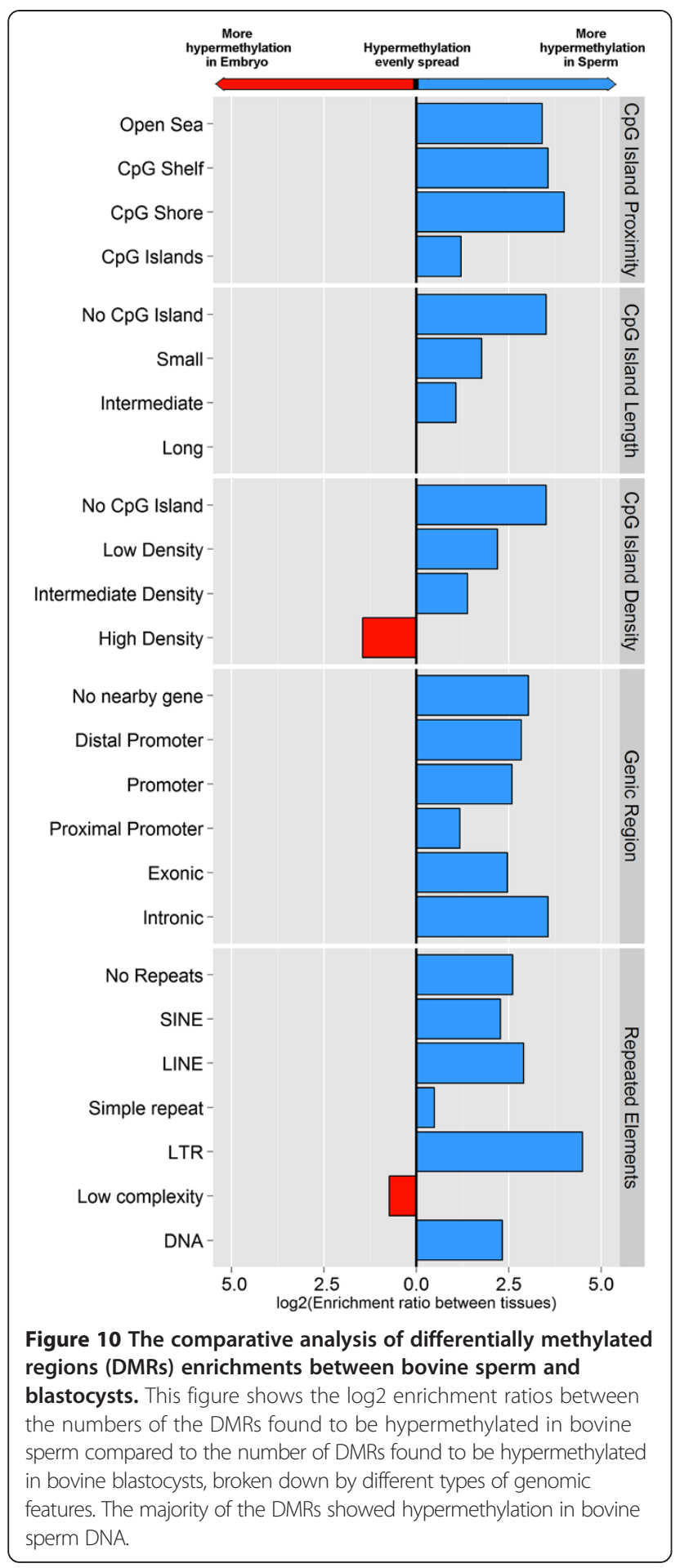

approaches using antibody or methyl-binding proteins have not been thoroughly tested with samples containing only a few ng of DNA. With larger DNA input, these methods have been shown to provide moderate resolution, since the capture depends on fragment methylation density [11,52].

While epigenome-wide association studies and the development of technological platforms suitable for low input DNA are broadening in scope, improvement to the standardization of experimental assays across samples and to data analysis and interpretation remains slow [53]. Although amplicons obtained by LM-PCR could be processed into sequencing libraries, we opted for microarray-based identification, which is more restrictive (being limited to the probes printed on the array) but has the major benefit of compatibility with an established, robust and user-friendly data analysis pipeline. These features may limit genomic coverage but definitely increase sample turnover rate by decreasing the time required to interpret data.

In comparison to gene expression, which is most often limited to the study of protein encoded transcribed elements which account for little more than $1 \%$ of the eukaryote genome, profiling overall DNA methylation considers a vastly more complex diversity of sequences, which in turn complicate data analysis. We therefore sought to support data interpretation by binning the information according to genomic features. Such an approach increases the statistical power to identify subtle alterations in genome regions by avoiding $\mathrm{P}$ value dilution, through multipletesting corrections that include the vast majority of regions considered a priori unlikely to be differentially methylated [54]. The data analysis pipeline built in to our platform accounts for: i) site specificity (e.g. promoter, intron, and exon), ii) region (e.g. shore, shelf, open-sea) and iii) sequence composition (e.g. CpG island density and length). This is in accordance with recent recommendations for epigenome-wide association studies [53].

The enrichment categorization implemented in the data analysis pipeline is based on previous studies [49,55-60] and provides a full complement of graphic outputs. Even though the graphs might not all be relevant to all users, depending on the experimental design and biological hypothesis, are all produced automatically at no additional cost in time or resources on the part of the user. Overall, EDMA was developed as a cost-effective standardized platform that robustly profiles DNA methylation across the entire bovine genome. This sample processing platform is also complemented with bioinformatics supports for data analysis with the specific aim to aid data interpretation.

\section{The importance of genome-scale parallel analysis of the DNA methylome and transcriptome}

Current technological advances and the exponential growth of epigenetics studies in the past few years, in particular genome-wide studies, are advancing our knowledge and providing more evidence for the interdependence of epigenetic and genetic variations [53]. By providing genomewide parallel survey of the DNA methylome and the transcriptome for the same sample, EDMA offers a powerful tool for revealing highly relevant targets and potential associations between the DNA methylome 


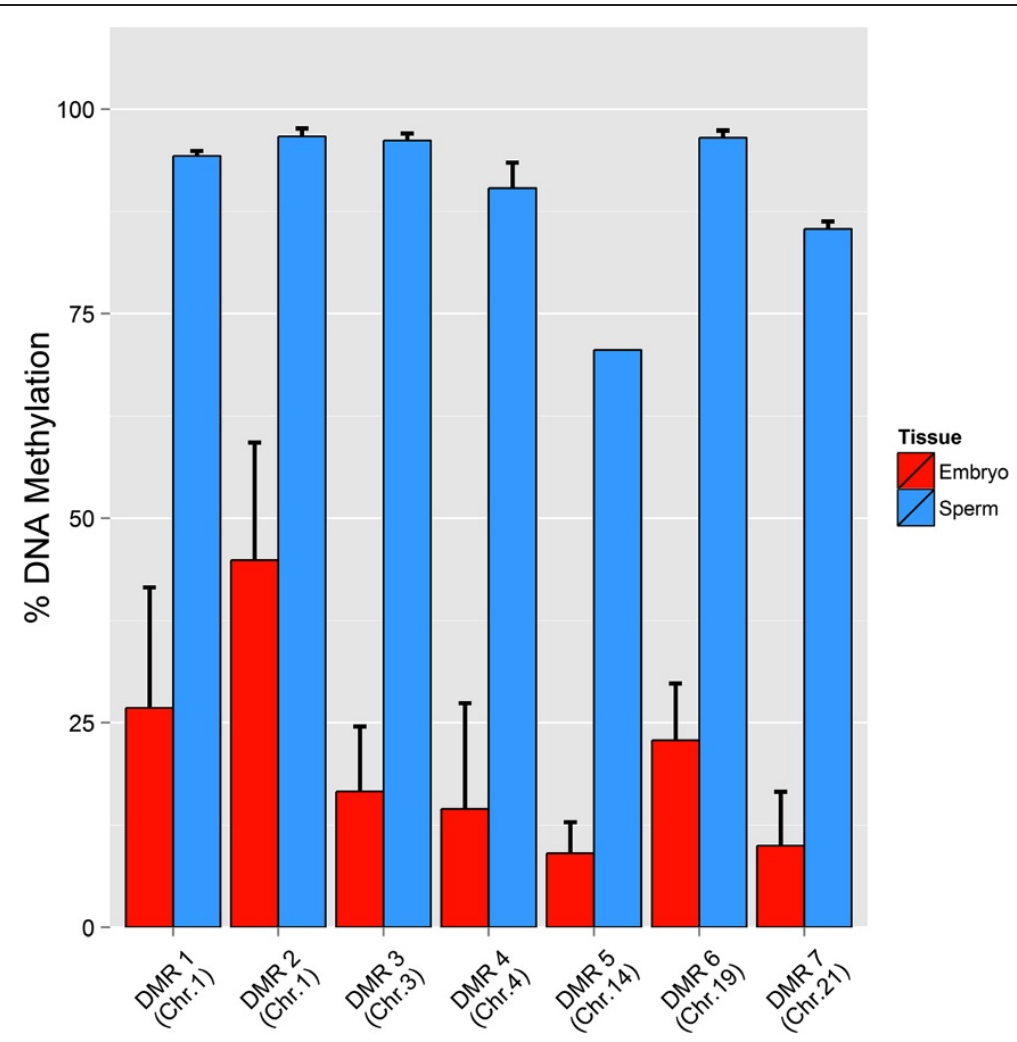

Figure 11 Validation of the selected DMRs by pyrosequencing.

and the transcriptome. In addition, overlaying methylomic and transcriptomic data has been shown to provide complementary information [60].

\section{Genome-wide profiles of bovine sperm and blastocyst DNA methylomes}

As proof of concept, we compared the DNA methylation profiles of bovine sperm and blastocysts and performed validation by pyrosequencing on selected DMRs. All selected candidates were found to be substantially more highly methylated in sperm DNA, corroborating the results obtained with EDMA. Physiologically relevant data were also generated and compared to the current literature. The sperm genome was found hyper-methylated compared to the embryo, which is consistent with the demethylation process known to occur after fertilization in bovine [61] and other species such as mouse [49,50] and zebra fish [62]. The data also indicated that large numbers of loci methylated in bovine embryos are also methylated in sperm DNA, which also corroborates a previous report [62]. As previously observed in mice [50], we found that from the DMRs enrichment, that short length/low density CpG islands showed a higher tendency to changes (i.e. being a DMR) than other regions. The direction of change is predominantly toward hypermethylation in sperm, but not always. In addition, we observed a high level of methylation in many repetitive elements, which is also in agreement with the patterns observed in mice $[49,50]$.

We observed marked differences (more hypermethylated DMRs in sperm) in the extent of methylation in long-terminal-repeat (LTR) retrotransposon, similar to previous findings with mice [50]. Furthermore, it has been shown that the sperm contributed DMRs in preimplantation embryos at LTRs were associated with reduction of DNA methylation and the most drastic methylation changes (reduction) in the sperm-to-zygote transition observed in some families of LINE and LTR retrotransposon [49]. In our previous report, we also observed a transition in DNA methylation in LTR during bovine embryo development from Day 7 to Day 12 [27].

The reason for the observed large difference in LTR methylation during early development and, as shown specifically in this study, between sperm and blastocysts is not yet clear, although these differences might reflect the importance of de novo establishment of genomewide methylation in the bovine early embryo. In this regard, robust LTR retrotransposon up-regulation has been shown during activation of the bovine embryo genome [63] and found to be a general requirement for progression through to the cleavage stage in mouse embryos $[64,65]$. However, the nature of its role in mammalian 
early development remains elusive. Furthermore, it has been suggested that LTR re-methylation occurs in the early, rather than late, pre-implantation mouse embryo [64]. Furthermore, the observation that a higher number of DMRs are present in low-complexity simple repeats in bovine blastocysts, in comparison with sperm, might represent notable dynamic changes in $5 \mathrm{mC}$ in these specific class of repetitive elements during bovine early embryo development and differentiation [66].

\section{Conclusion}

By developing EDMA, we are providing a unified and reliable approach to analyze small amounts of genomic DNA, one that offers a good balance between genomic coverage and data turnaround time. The use of a microarray for fragment identification is robust, efficiently minimizing sample-to-data time. The built-in data analysis pipeline provides efficient means for data interpretation. The integrated data analysis pipeline could be a good option for researchers with limited bioinformatics resources. The platform is at the present time specific for the bovine genome, but a similar approach could be adapted easily to any species of which the entire genome is known. Such platforms enable the study of the potential epigenetic risks associated with assisted reproductive technologies (ART) or to highlight the sequence of events occurring during the establishment of embryonic cell lines.

\section{Methods}

\section{Ethics statement}

Experiments took place in compliance with the guidelines of the Canadian Council on Animal Care and supervised by the Animal Protection Committee of Université Laval. These guidelines are strictly followed by the local abattoir and L'Alliance Boviteq who provided all the tissues and samples. The study did not require handling animals on university premises.

\section{Microarray design}

The design of the EmbryoGENE (http://embryogene.ca) DNA Methylation Array (EDMA) was based on a compilation of methylation-sensitive genetic loci found previously to be involved in early embryonic development [27]. To maximize genomic coverage, all probes on the EDMA array were designed on the assumption that genomic cleaving using the MseI (T/TAA) restriction endonuclease would be nearly complete. All probes therefore targeted a specific MseI-MseI fragment within the bovine genome. Target loci were selected on the basis of their proximity to either the putative sites identified in our previous study [27] or to known $\mathrm{CpG}$ islands. Tiling of fragments neighboring the selected loci was then carried out until enough loci were selected to fill one Agilent SurePrint $1 \times 1 \mathrm{M}$ slide (Agilent
Technologies). Test hybridizations were carried out, and the best-performing 400,000 probes were selected for placement on the final Agilent SurePrint $2 \times 400 \mathrm{~K}$ array. Probe quality was measured by assessing sequence specificity and signal strength variation across the set of test hybridizations. The final EDMA array (EDMA.V2) contains 414,566 probes targeting 359,738 loci, surveying 20,355 genes and 34,379 CpG islands. The microarray also contains 10,388 control probes accounting for $2.5 \%$ of all the total probes, representing 5,610 Agilent proprietary spiked-in controls, 4,634 genomic cleavage controls and 144 EDMA spiked-in methylation controls. Controls were designed with an MseI restriction site at their center and were tiled at every $1 \mathrm{M}$ base pairs throughout the bovine genome. These were used to assess the degree of genomic digestion. The EDMA spiked-in controls are exogenous DNA fragments (Solanum lycopersicum) chosen for their lack of homology with the bovine genome and for the presence of specific HpaII, AciI and HinP1I restriction sites within their sequence. They were artificially methylated or left unmethylated to provide positive and negative controls for the methylation-sensitive cleavage. Probe design for the EDMA microarray was carried out by Genotypic Inc. (Bangalore, India). The arrays were printed using the SurePrint technology (Agilent Technologies). The details of the EDMA platform array have been deposited in NCBI's Gene Expression Omnibus (GEO) (http://www. ncbi.nlm.nih.gov/geo/) and are accessible through GEO, Platform accession number: GPL18384.

\section{Sample production and genomic DNA extraction}

Bovine blastocyst production in synthetic oviduct fluid (SOF) media was performed as described previously [27]. The ovaries were collected at a local abattoir which is complying with the guidelines provided by the Canadian Council on Animal Care. Only expanded-blastocyst-stage embryos were collected, in four pools of ten embryos $(n=40)$. All embryos were washed three times with RNAse-free phosphate-buffered saline (PBS) prior to snap-freezing and storage at $-80^{\circ} \mathrm{C}$. Extraction of genomic DNA was carried out using an AllPrep DNA/RNA Mini Kit (QIAGEN, Mississauga, ON, Canada), and samples were eluted in $30 \mu \mathrm{L}$. Straws containing frozen semen from Holstein bulls were obtained from L'Alliance Boviteq Inc (Saint-Hyacinthe, QC, Canada). L'Alliance Boviteq Inc is a commercial service provider also complying with the guidelines provided by the Canadian Council on Animal Care. Sperm genomic DNA was extracted using lysis buffer, followed by ethanol precipitation. The quality and quantity of extracted DNA were analyzed by optical absorbance using a Nanodrop ND-1000 spectrophotometer (NanoDrop Technologies Inc.) and by electrophoresis on $0.5 \%$ agarose gel at 45 volts for $2 \mathrm{~h}$. 


\section{Sample treatment}

The same DNA input (10 ng) was used for both embryo and sperm samples. For quality control purposes, all samples were spiked in with a mixture of six synthetic DNA constructs harbouring MseI restriction sites at each end. One pair of constructs was designed for each methyl-sensitive restriction enzyme (HpaII, HinP1I and Aci1I) to be used in the fragment selection process. For each pair, one control DNA fragment was methylated in vitro using $\mathrm{CpG}$ methyltransferase M.SssI (New England Biolabs). The difference between the extents of cleavage obtained with each pair was used to calculate cleavage efficiency. Residual MseI sites within the fragments were measured after processing to determine the extent of genomic fragmentation.

Sample (in $30 \mu \mathrm{L}$ of elution buffer) plus $0.5 \mu \mathrm{L}$ of bovine serum albumin (New England Biolabs), $5 \mu \mathrm{L}$ of $10 \times$ Buffer 4 (New England Biolabs) and $28 \mu \mathrm{L}$ of DNAse/ RNAse free water were divided into two equal fractions and fragmented using $10 \mathrm{U}$ of $\mathrm{MseI}$ (New England Biolabs) as follows, $16 \mathrm{~h}$ at $37^{\circ} \mathrm{C}$ followed by $65^{\circ} \mathrm{C}$ for $20 \mathrm{~min}$. The two fractions were combined and DNA was concentrated by ethanol precipitation following addition of $5 \mu \mathrm{g}$ of linear acrylamide solution (Ambion) as carrier and $5 \mu \mathrm{L}$ of sodium acetate buffer $(3 \mathrm{M}$, $\mathrm{pH}$ 5.5, Ambion Inc.). The pellet was washed twice with $70 \%$ ethanol, air-dried and resuspended in $5 \mu \mathrm{L}$ of DNAse/RNAse free water.

Fragmented genome DNA adapter ligation Adaptors were ligated to the MseI digested genomic fragments as described previously [40]. Briefly, $5 \mu \mathrm{M}$ of each primer (MseLig 21: 5' -AGT GGG ATT CCG CAT GCT AGT3', MseLig 12: 5' -TAA CTA GCA TGC-3', IDT DNA), 0.5× One-Phor-All plus Buffer (Pharmacia Biotech) and $1.5 \mu \mathrm{L}$ of nuclease-free water were added to the sample. Annealing was initiated at $65^{\circ} \mathrm{C}$ for $1 \mathrm{~min}$, and the temperature was ramped at $1^{\circ} \mathrm{C} / \mathrm{min}$ down to $15^{\circ} \mathrm{C}$. T4 DNA ligase (5 units, Boehringer Mannheim) and $10 \mathrm{nmol}$ of ATP were added and the reaction and incubated for $16 \mathrm{~h}$ at $15^{\circ} \mathrm{C}$.

HpaII tiny fragment enrichment by ligation-mediated PCR (HELP) cocktail cleavage of ligated genomic DNA The ligated sample was triple-cleaved with FastDigest ${ }^{\mathrm{mm}}$ methyl-sensitive restriction endonucleases (MSRE) HpaII (C/CGG), HinP1I (GC/GC), Aci1I (C/CGC) (Fermentas Thermo Fisher Scientific) using a sequential digestion. Samples were first digested in $50 \mu \mathrm{L}$ reactions that included $10 \mu \mathrm{L}$ of sample, $0.5 \mu \mathrm{L}$ of HpaII, $0.5 \mu \mathrm{L}$ of HinP1I, $5 \mu \mathrm{L}$ of $10 \times$ FastDigest buffer and $34 \mu \mathrm{L}$ of nuclease-free water for $12 \mathrm{~h}$ at $37^{\circ} \mathrm{C}$. A second cleavage was performed by adding $0.5 \mu \mathrm{L}$ of Aci1I, $5 \mu \mathrm{L}$ of $10 \times$ FastDigest buffer and $44.5 \mu \mathrm{L}$ of nuclease-free water and incubating at $37^{\circ} \mathrm{C}$ for $4 \mathrm{~h}$, followed by thermal inactivation at $85^{\circ} \mathrm{C}$ for $10 \mathrm{~min}$.

Verification of cleavage: qPCR of spiked-in templates The extent of cleavage by MSREs was determined using qPCR detection of spiked-in controls. A master mixture $(19 \mu \mathrm{L})$ containing $2 \mathrm{mM} \mathrm{MgCl} 2,1 \times$ LightCycler FastStart DNA Master SYBR Green mix (Roche Diagnostics Canada, Laval, QC, Canada), $14.4 \mu \mathrm{L}$ of nuclease-free water and $1 \mu \mathrm{L}$ of cleaved sample (template) was divided into three fractions to which $0.25 \mu \mathrm{M}$ of each forward and reverse primer designed to target the appropriate control template was added (see Additional file 2: Table S1). Each qPCR run also included a positive control (non-digested spiked-in, 1/1000 dilution) and negative control (no template). The qPCR conditions were as follows: initial denaturation was carried out at $95^{\circ} \mathrm{C}$ for 10 minutes, followed by 50 amplification cycles at $95^{\circ} \mathrm{C}$ for 5 seconds, $52^{\circ} \mathrm{C}$ for 5 seconds and $72^{\circ} \mathrm{C}$ for 20 seconds. Melting curve analysis was performed for 1 cycle with a ramp rate of $0.2^{\circ} \mathrm{C}$ per second, starting at $94^{\circ} \mathrm{C}$ for 5 seconds, $72^{\circ} \mathrm{C}$ for 30 seconds, and back to $94^{\circ} \mathrm{C}$ for 0 seconds, and cooling at $40^{\circ} \mathrm{C}$.

Amplicon specificity was determined from the shape of the melting curve and the difference in cycle threshold $(\Delta \mathrm{Ct})$ between methylated (MSRE cleavage protected) and unmethylated (MSRE cleavage unprotected) templates was used to calculate cleavage efficiency. The DNA samples were then precipitated by ethanol, washed and dissolved in $10 \mu \mathrm{L}$ of nuclease-free water.

Fragment selection by ligation-mediated PCR Selective amplification of methylated fragments was performed using two rounds of ligation-mediated PCR (LM-PCR) as described previously [40], with some modifications. The first LM-PCR amplification was carried out in $50 \mu \mathrm{L}$ using $10 \mu \mathrm{L}$ of sample to which $1 \mu \mathrm{M}$ of primers (MseLig12 and MseLig21) was added, 0.1× One-Phor-All plus Buffer (Pharmacia Biotech), 0.6 $\times$ Ex Taq ${ }^{\text {mix }}$ buffer without $\mathrm{Mg}^{2+}$ (TaKaRa), $0.1 \mathrm{U}$ Ex Taq ${ }^{\text {Tam }}$ enzyme (TaKaRa), $1.5 \mathrm{mM} \mathrm{MgCl}, 0.4 \mathrm{mM} \mathrm{dNTP}$, and $23.5 \mu \mathrm{L}$ of nucleasefree water. The mixture was then subjected to thermal cycling as follows: $94^{\circ} \mathrm{C}(40 \mathrm{sec}), 57^{\circ} \mathrm{C}(30 \mathrm{sec})$ and $72^{\circ} \mathrm{C}(1 \mathrm{~min}$ $15 \mathrm{sec})$ for 15 cycles; $94^{\circ} \mathrm{C}(40 \mathrm{sec}), 57^{\circ} \mathrm{C}(30 \mathrm{sec})$ and $72^{\circ} \mathrm{C}$ $(1 \mathrm{~min}, 45 \mathrm{sec})$ for $34 \mathrm{cycles}$; and $94^{\circ} \mathrm{C}(40 \mathrm{sec}), 57^{\circ} \mathrm{C}$ ( $30 \mathrm{sec}$ ) and $72^{\circ} \mathrm{C}(5 \mathrm{~min}$ ) for the final cycle. The PCR products were resolved on $1 \%$ agarose gel to assess the quality.

To obtain sufficient DNA for downstream processing, three PCR reactions were carried out using $0.75 \mu \mathrm{L}$ aliquots from the first LM PCR, to which $1.5 \mu \mathrm{M}$ MseLig21 primer was added, plus $1 \times$ Buffer 1 (Roche/Boehringer Mannheim, Expand Long Template), $0.2 \mathrm{mM}$ dNTPs, $0.8 \mu \mathrm{L}$ of Expand Long Template Enzyme Mix (Roche/Boehringer Mannheim) and $38.7 \mu \mathrm{L}$ of nuclease-free water. The 
following four-step programs were used: $94^{\circ} \mathrm{C}$ (60 sec), $65^{\circ} \mathrm{C}$ (30 sec), and $72^{\circ} \mathrm{C}(2 \mathrm{~min})$ for $1 \mathrm{cycle} ; 94^{\circ} \mathrm{C}(40 \mathrm{sec})$, $65^{\circ} \mathrm{C}(30 \mathrm{sec})$ and $72^{\circ} \mathrm{C}(90 \mathrm{sec})$ for 14 cycles; $94^{\circ} \mathrm{C}(40 \mathrm{sec})$, $65^{\circ} \mathrm{C}(30 \mathrm{sec})$ and $72^{\circ} \mathrm{C}(2 \mathrm{~min})$ for 9 cycles and $72^{\circ} \mathrm{C}$ (5 min) as the final cycle. The quality and concentration of DNA were evaluated as described above.

Adaptor removal The amplified product from the second LM-PCR was purified using a QIAquick PCR Purification Kit (Qiagen) according to the manufacturer's instructions with minor modifications. Final elution volume was $41.5 \mu \mathrm{L}$, of which $1.5 \mu \mathrm{L}$ was used for quantification by absorbance measurement. The rest was divided in two separate $20 \mu \mathrm{L}$ aliquots. Adaptors were removed by digestion for $16 \mathrm{~h}$ at $37^{\circ} \mathrm{C}$ with $1 \mathrm{U}$ of $\mathrm{MseI}$ (New England Biolabs). The mixture also contained $1 \times$ bovine serum albumin (New England Biolabs, Ipswich, MA, USA), $1 \times$ Buffer 4 (New England Biolabs), and $24 \mu \mathrm{L}$ of nuclease-free water. The reaction was terminating by heating for $20 \mathrm{~min}$ at $65^{\circ} \mathrm{C}$. The sample was then purified using a QIAquick PCR Purification Kit (Qiagen), eluted in $23.5 \mu \mathrm{L}$ of nuclease-free water and quantified by absorbance.

Sample labeling and hybridization For each sample, $2.5 \mu \mathrm{g}$ of DNA was labeled using the Universal Linkage System (ULS) labeling kit (Kreatech Biotechnology) according to the manufacturer's instructions with minor modifications: $1 \mu \mathrm{L}$ of Cy-ULS dye was added per $1 \mu \mathrm{g}$ of genomic DNA adjusted with $10 \times$ labeling buffer. The labelling mixture was then held for $30 \mathrm{~min}$ at $85^{\circ} \mathrm{C}$ in a thermocycler, followed by $3 \mathrm{~min}$ on ice. Non-reacted ULS-Cy3/5 was removed by purification using a QIAquick PCR Purification Kit and samples were eluted in $23.5 \mu \mathrm{L}$ nuclease-free water. A $1.5 \mu \mathrm{L}$ aliquot was used to determine DNA concentration and dye incorporation using the ND1000 NanoDrop. Hybridizations were performed according to the microarray manufacturer's instructions (Agilent Technologies). Briefly, $1 \mu \mathrm{g}$ of labeled sample (in $40 \mu \mathrm{L}$ ) was mixed with $158 \mu \mathrm{L}$ of hybridization master mix containing $25 \mu \mathrm{L}$ of bovine Cot-1 DNA $(1.0 \mathrm{mg} / \mathrm{mL}$, Bovine Hybloc competitor DNA, Applied Genetics Laboratories), $2.6 \mu \mathrm{L}$ of Agilent 100x Blocking Agent and $130 \mu \mathrm{L}$ of Agilent 2× HI-RPM Hybridization Buffer (Agilent Technologies). Samples were held at $95^{\circ} \mathrm{C}$ for $3 \mathrm{~min}$ and at $37^{\circ} \mathrm{C}$ for $30 \mathrm{~min}$ followed by addition of $65 \mu \mathrm{L}$ of Agilent-CGHBlock (final volume $260 \mu \mathrm{L}$ ). The samples were loaded onto the microarray and hybridization was carried out in a hybridization oven (Shel Lab) for $40 \mathrm{~h}$ at $65^{\circ} \mathrm{C}$ and $20 \mathrm{rpm}$. Washing was carried out according to the microarray manufacturer's instructions and slides were scanned with the PowerScanner (Tecan) and analyzed with Array-Pro Analyzer 6.3 software (MediaCybernetics).

\section{Bioinformatics}

Data analysis pipeline To complement our transcriptomic platform [1], a complete suite of data analysis tools was added and integrated into the EmbryoGENE LIMS and Microarray Analysis (ELMA) gateway (http:// elma.embryogene.ca/). This pipeline processes sampleassociated information, experimental design and protocols, as well as microarray data analysis for identification of differential gene/loci lists and further data mining for enrichment analyses. EDMA data was analyzed using the Limma package from Bioconductor [67,68]. First, Loess intra-array normalization followed by quantile inter-array scale normalization were applied. Normalized data was then fitted to a linear model and Bayesian statistics of differential expression were obtained. Differences in DNA methylation were considered significant when the $\mathrm{P}$ value was $<0.05$ and the absolute $\log 2$ foldchange was at least 1.5. The inter-treatment comparisons were conducted using between-group analysis based on Eigen values using the Bioconductor package MADE4 [69]. Visualization tools were developed to generate plots of the extent of cleavage of spiked-in controls and overall genomic cleavage for quality control purposes. Different plots including Volcano plots were generated to visualize the amount of differentially methylated regions among treatments. Normalized data and a list of differentially methylated loci can be exported as text files for downstream data mining. Different enrichment analyses for genome-scale DNA methylation data are performed through a string of integrated scripts that categorize the information based on CpG island density [49], CpG island length [57], CpG island distance [58], genomic location and types of repetitive elements [70]. The pipeline also pinpoints methylation hot spots, generates bedgraph files appropriate for visualization within a genome browser, and uses Circos plot [71] to generate a circular graph representing overall methylation levels and correlating these to transcription levels, if the latter data are available.

Parameters definitions The CpG island lengths, density and positions for the UMD3.1 (ftp://ftp.cbcb.umd.edu/ pub/data/assembly/Bos_taurus/) build of the bovine genome was obtained from the UCSC genome browser [72]. For any given gene in EDMA, there are five types of annotation "windows" including; 1) Distal promoter, 2) Promoter, 3) Proximal Promoter, 4) Exons and 5) Introns. The "Proximal Promoter", "Promoter" and "Distal Promoter" regions are defined as the first 1 kbp, $5 \mathrm{kbp}$ and $50 \mathrm{kbp} \mathrm{5'}$ of the transcription start site (TSS). For each probes, genes are added to the appropriate columns if their MseI-MseI fragment overlap those windows. Genomic locations which were not 
part of a CpG island were further split into three types based on their distance from the nearest $\mathrm{CpG}$ island: "CpG shores" for regions within 2,000 nucleotides of an island, "CpG shelves" for regions between 2,000 and 4,000 nucleotides of an island and "Open Sea" for regions further away [58]. Probes whose fragment overlaps a $\mathrm{CpG}$ island were annotated using the descriptive characteristics of that island. Of all $\mathrm{CpG}$ island surveyed by the array, those in the bottom 20 percentile of length were classified as "short", those at the top 80 percentile were classified as "long" and all others were classified as "intermediate" [57]. The same scheme was applied to CpG island density, with the bottom 20 percentile being labelled "low density", the top 80 percentile being labelled "high density", and all others being labelled "Intermediate density" [49]. Bovine repetitive elements content were identified by RepeatMasker (http://www.repeatmasker.org/) with build 20120418 of the RepBase database [70] and then used the repeat classes attribute (LINE, SINE, etc.) as a basis for category enrichment. The "methylation hot spots" is calculated as the averages p-values of differential methylation over windows of $100 \mathrm{~K}$ nucleotides. More specifically, for all probes on the array, we look up all other probes within $100 \mathrm{~K}$ nucleotides upstream and downstream, and average the $\mathrm{p}$-values thus obtained. The averaged $\mathrm{p}$ values have no statistical meaning, but can be used as an indicator for regions of interest, which we called a "methylation hot spot".

\section{Data validation}

Pyrosequencing was performed as described previously [73]. Briefly, blastocyst and sperm DNA samples were bisulfite-converted using an EZ DNA methylation direct KIT, (ZYMO Research) followed by amplification of target loci by PCR prior to sequencing. For all pyrosequencing assays, PyroMark Assay Design software (Qiagen) was used to design three oligonucleotide primers (forward, reverse and sequencing), synthesized by Integrated DNA technologies (Coralville). All reverse primers were biotinylated at the $5^{\prime}$ terminus and purified by HPLC. PCR amplification was carried out in $25 \mu \mathrm{L}$ containing $0.2 \mu \mathrm{M}$ of each forward and reverse 5 '-biotinylated primer, $1.25 \mathrm{U}$ of Platinum Taq DNA polymerase (Invitrogen), $1 \times$ Taq DNA polymerase buffer, $0.2 \mathrm{mM}$ dNTPs, $3-4 \mathrm{mM} \mathrm{MgCl}$, $2 \mu \mathrm{L}$ of bisulfite-treated DNA and $17.5 \mu \mathrm{L}$ of nuclease-free water. The following three-step program was used: $95^{\circ} \mathrm{C}$ (5 min) for 1 cycle, $95^{\circ} \mathrm{C}$ (30 sec), $48^{\circ} \mathrm{C}$ for DMR $1 \mathrm{~b}, 49^{\circ} \mathrm{C}$ for DMRs 2 and $3 \mathrm{a}, 50^{\circ} \mathrm{C}$ for DMRs $1 \mathrm{a}, 3 \mathrm{~b}, 5-8$ and $54^{\circ} \mathrm{C}$ for DMR 4 ( $30 \mathrm{sec})$ and $72^{\circ} \mathrm{C}(30 \mathrm{sec})$ for 35 cycles, and finally $72^{\circ} \mathrm{C}(5 \mathrm{~min})$. The specificity of the amplification was verified by electrophoresis on $2 \% \mathrm{w} / \mathrm{v}$ agarose gel at $90 \mathrm{~V}$ for $45 \mathrm{~min}$. Templates were purified by adding $2 \mu \mathrm{L}$ of streptavidin-coated Sepharose beads (GE Healthcare) in the presence of $40 \mu \mathrm{L}$ of binding buffer (Qiagen) and then pyrosequenced [74]. Pyrosequencing reactions were conducted using a PyroMark Q24 apparatus (Qiagen).

\section{Availability of supporting data}

The data analysis pipeline user manual is available at; [EDMA user manual]: http://emb-bioinfo.fsaa.ulaval.ca/ bioinfo/html/epigenetics/Epigenetics\%20Analysis\% 20Pipeline.pdf.

The dataset of microarray results have been deposited in NCBI's Gene Expression Omnibus (GEO) and are accessible through GEO series accession number: GSE57709 (http://www.ncbi.nlm.nih.gov/geo/query/acc.cgi? acc=GSE57709).

\section{Additional files}

Additional file 1: Figure S1. (A) This histogram shows the in silico analysis of the lengths of Msel/Msel fragments across the bovine genome. Higher frequencies of shorter fragments with an average size $<160$ bp are observed. (B) The Venn diagram shows the overlaps between restriction sites of the HELP cocktail MSREs within the genomic Msel fragments targeted by EDMA probes. Figure S2. This figure shows the histogram number of (A) CpG dinucleotide per Msel restriction fragments and histograms number of MSREs ((B) Hpall; (C) HinP1l; (D) Acil) restriction sites per restriction fragments in EDMA. Figure S3. This figure clearly shows that there is not any correlation between the determined EDMA fold change and Pyrosequening results due to the enrichment-based nature of the applied protocol.

Additional file 2: Table S1. The designed Primers for the MSRE digestion quality control step. Table S2. Genomic and CpG coverage by Msel fragments targeted by EDMA probes as a function of the MSRE sites present within those fragments. Table S3. Gene and CpG Island coverage by EDMA probes. Table S4. Breakdown of the location of EDMA probes in relation to annotated features of the bovine genome. Table S5. The properties of the selected hypermethylated DMRs and their primers designed used for pyrosequencying.

\section{Abbreviations}

ART: Assisted reproductive technologies; DMR: Differentially methylated region; EDMA: EmbryoGENE DNA methylation analysis; ELMA: EmbryoGENE LIMS and microarray analysis; HELP: Hpall tiny fragment enrichment by ligation-mediated PCR; LINE: Long interspersed element; LM-PCR: Ligationmediated PCR; LTR: Long terminal repeat retrotransposons; MSRE: Methylsensitive restriction endonuclease; ncRNA: Non-coding RNA;

NNAT: Neuronatin gene; PEG10: Paternally expressed 10 gene; QC: Quality control; RRBS: Reduced-representation bisulfite sequencing; SINE: Short interspersed element.

\section{Competing interests}

The authors declare they have no competing interest.

\section{Authors' contributions}

HASS worked on platform development, performed bovine sperm and blastocyst experiments, and designed the analysis pipeline. AOD performed pyrosequencing for candidates. DG was involved in platform development. EF performed bioinformatic analyses, array design and programmed the plot generation pipeline. JG performed the in silico survey of $\mathrm{CPG}$ islands. MAS and CR conceived the general strategy for the platform's development. CR designed and supervised the work. HASS and CR drafted the final manuscript. All authors read and approved the final manuscript.

\section{Acknowledgements}

Shojaei Saadi H. A. supported by EmbryoGENE, REDIH and RQR-CREATE scholarships. This work was supported by a grant from the Natural Sciences 
and Engineering Research Council of Canada (grant number: NETGP-34082506). This grant was awarded from the Strategic Research Network program supporting the EmbryoGENE Network (www.embryogene.ca).

\section{Author details}

'Laboratory of Functional Genomics of Early Embryonic Development, Institut des nutraceutiques et des aliments fonctionnels, Faculté des sciences de l'agriculture et de l'alimentation, Pavillon des services, Université Laval, Québec G1V 0A6, Canada. ${ }^{2}$ School of Agriculture, Food Science \& Veterinary Medicine, University College Dublin, Belfield, Dublin, Ireland. ${ }^{3}$ Department of Agricultural, Food and Nutritional Science, University of Alberta, Edmonton, AB T6G 2P5, Canada.

Received: 17 February 2014 Accepted: 28 May 2014

Published: 9 June 2014

\section{References}

1. Robert C, Nieminen J, Dufort I, Gagné D, Grant J, Cagnone G, Plourde D, Nivet A-L, Fournier É, Paquet É, Blazejczyk M, Rigault P, Juge N, Sirard MA: Combining resources to obtain a comprehensive survey of the bovine embryo transcriptome through deep sequencing and microarrays. Mol Reprod Dev 2011, 78(9):651-664.

2. Tsoi S, Zhou C, Grant J, Pasternak J, Dobrinsky J, Rigault P, Nieminen J, Sirard M-A, Robert C, Foxcroft G, Dyck MK: Development of a porcine (Sus scofa) embryo-specific microarray: array annotation and validation. BMC Genomics 2012, 13(1):370,

3. Gad A, Hoelker M, Besenfelder U, Havlicek V, Cinar U, Rings F, Held E, Dufort I, Sirard MA, Schellander K, Tesfaye D: Molecular mechanisms and pathways involved in bovine embryonic genome activation and their regulation by alternative in vivo and in vitro culture conditions. Biol Reprod 2012, 87(4):100.

4. Cagnone GLM, Sirard M-A: Transcriptomic signature to oxidative stress exposure at the time of embryonic genome activation in bovine blastocysts. Mol Reprod Dev 2013, 80(4):297-314.

5. Cagnone GL, Dufort I, Vigneault C, Sirard MA: Differential gene expression profile in bovine blastocysts resulting from hyperglycemia exposure during early cleavage stages. Biol Reprod 2012, 86(2):50.

6. Zhang P, Zucchelli M, Bruce S, Hambiliki F, Stavreus-Evers A, Levkov L, Skottman H, Kerkelä E, Kere J, Hovatta O: Transcriptome profiling of human pre-implantation development. PLoS One 2009, 4(11):e7844.

7. Hamatani T, Carter M, Sharov A, Ko M: Dynamics of global gene expression changes during mouse preimplantation development. Dev Cell 2004, 6(1):117-131.

8. Léandri R, Archilla C, Bui L, Peynot N, Liu Z, Cabau C, Chastellier A, Renard J, Duranthon $V$ : Revealing the dynamics of gene expression during embryonic genome activation and first differentiation in the rabbit embryo with a dedicated array screening. Physiol Genomics 2009, 36(2):98-113.

9. Szyf M: The early life environment and the epigenome. Biochim Biophys Acta 2009, 1790(9):878-885

10. Guerrero-Bosagna C, Skinner M: Environmentally induced epigenetic transgenerational inheritance of phenotype and disease. Mol Cell Endocrinol 2011, 354((1-2)):3-8.

11. Suzuki MM, Bird A: DNA methylation landscapes: provocative insights from epigenomics. Nat Rev Genet 2008, 9(6):465-476.

12. Bernstein B, Meissner A, Lander E: The mammalian epigenome. Cell 2007, 128(4):669-681.

13. Baccarelli A, Rienstra M, Benjamin EJ: Cardiovascular epigenetics: basic concepts and results from animal and human studies. Circ Cardiovasc Genet 2010, 3(6):567-573.

14. Shi $L$, Wu J: Epigenetic regulation in mammalian preimplantation embryo development. Reprod Biol Endocrinol 2009, 7(1):59.

15. Bird A: DNA methylation patterns and epigenetic memory. Genes Dev 2002, 16(1):6-21.

16. Raynal N, Si J, Taby R, Gharibyan V, Ahmed S, Jelinek J, Estécio M, Issa J-PJ: DNA methylation does not stably lock gene expression but instead serves as a molecular mark for gene silencing memory. Cancer Res 2012 , 72(5):1170-1181.

17. Talens RP, Boomsma DI, Tobi EW, Kremer D, Jukema JW, Willemsen G, Putter H, Slagboom PE, Heijmans BT: Variation, patterns, and temporal stability of DNA methylation: considerations for epigenetic epidemiology. FASEB J 2010, 24(9):3135-3144.
18. Fraga MF, Ballestar E, Paz MF, Ropero S, Setien F, Ballestar ML, Heine-Suñer D, Cigudosa JC, Urioste M, Benitez J, Boix-Chornet M, Sanchez-Aguilera A, Ling C, Carlsson E, Poulsen P, Vaag A, Stephan Z, Spector TD, Wu YZ, Plass C, Esteller M: Epigenetic differences arise during the lifetime of monozygotic twins. Proc Natl Acad Sci USA 2005, 102(30):10604-10609.

19. Wu H, Zhang Y: Early embryos reprogram DNA methylation in two steps. Cell Stem Cell 2012, 10(5):487-489.

20. Seisenberger S, Peat JR, Reik W: Conceptual links between DNA methylation reprogramming in the early embryo and primordial germ cells. Curr Opin Cell Biol 2013, 25(3):281-288.

21. Reik W, Dean W, Walter J: Epigenetic reprogramming in mammalian development. Science 2001, 293(5532):1089-1093.

22. Morgan HD, Santos F, Green K, Dean W, Reik W: Epigenetic reprogramming in mammals. Hum Mol Genet 2005, 14(suppl 1):R47-R58.

23. Seisenberger S, Peat JR, Hore TA, Santos F, Dean W, Reik W: Reprogramming DNA methylation in the mammalian life cycle: building and breaking epigenetic barriers. Philos Trans R Soc B Biol Sci 2013, 368(1609):20110330.

24. Santos F, Hendrich B, Reik W, Dean W: Dynamic Reprogramming of DNA Methylation in the Early Mouse Embryo. Dev Bio/ 2002, 241(1):172-182.

25. van Montfoort APA, Hanssen LLP, de Sutter P, Viville S, Geraedts JPM, de Boer $P$ : Assisted reproduction treatment and epigenetic inheritance. Hum Reprod Update 2012, 18(2):171-197.

26. McGraw S, Shojaei Saadi HA, Robert C: Meeting the methodological challenges in molecular mapping of the embryonic epigenome. Mol Hum Reprod 2013, 19(12):809-827.

27. de Montera B, Fournier E, Shojaei Saadi HA, Gagne D, Laflamme I, Blondin P, Sirard MA, Robert C: Combined methylation mapping of $5 \mathrm{mC}$ and $5 \mathrm{hmC}$ during early embryonic stages in bovine. BMC Genomics 2013, 14:406.

28. Irizarry RA, Ladd-Acosta C, Carvalho B, Wu H, Brandenburg SA, Jeddeloh JA, Wen $B$, Feinberg AP: Comprehensive high-throughput arrays for relative methylation (CHARM). Genome Res 2008, 18(5):780-790.

29. Slomko H, Heo HJ, Einstein FH: Minireview: epigenetics of obesity and diabetes in humans. Endocrinology 2012, 153(3):1025-1030.

30. Youngson NA, Morris MJ: What obesity research tells us about epigenetic mechanisms. Philos Trans R Soc B Biol Sci 2013, 368(1609):20110337.

31. Saab BJ, Mansuy IM: Neurobiological disease etiology and inheritance: an epigenetic perspective. J Exp Biol 2014, 217(1):94-101.

32. Tsankova N, Renthal W, Kumar A, Nestler EJ: Epigenetic regulation in psychiatric disorders. Nat Rev Neurosci 2007, 8(5):355-367.

33. lacobuzio-Donahue CA: Epigenetic changes in cancer. Annu Rev Pathol Mech Dis 2009, 4(1):229-249.

34. Dawson Mark A, Kouzarides T: Cancer epigenetics: from mechanism to therapy. Cell 2012, 150(1):12-27.

35. Rodriguez-Paredes $M$, Esteller M: Cancer epigenetics reaches mainstream oncology. Nat Med 2011, 17(3):330-339.

36. Feinberg AP: Phenotypic plasticity and the epigenetics of human disease. Nature 2007, 447(7143):433-440.

37. Kantlehner M, Kirchner R, Hartmann P, Ellwart JW, Alunni-Fabbroni M, Schumacher A: A high-throughput DNA methylation analysis of a single cell. Nucleic Acids Res 2011, 39(7):e44.

38. Denomme MM, Zhang L, Mann MR: Single oocyte bisulfite mutagenesis. J Vis Exp 2012, (64):e4046.

39. Lorthongpanich C, Cheow LF, Balu S, Quake SR, Knowles BB, Burkholder WF, Solter D, Messerschmidt DM: Single-cell DNA-methylation analysis reveals epigenetic chimerism in preimplantation embryos. Science 2013, 341(6150):1110-1112.

40. Klein C, Schmidt-Kittler O, Schardt J, Pantel K, Speicher M, Riethmüller G: Comparative genomic hybridization, loss of heterozygosity, and DNA sequence analysis of single cells. Proc Natl Acad Sci USA 1999, 96(8):4494-4499.

41. Oda M, Glass JL, Thompson RF, Mo Y, Olivier EN, Figueroa ME, Selzer RR, Richmond TA, Zhang X, Dannenberg L, Green RD, Melnick A, Hatchwell E, Bouhassira EE, Verma A, Suzuki M, Greally JM: High-resolution genome-wide cytosine methylation profiling with simultaneous copy number analysis and optimization for limited cell numbers. Nucleic Acids Res 2009, 37(12):3829-3839.

42. Hashimoto K, Kokubun S, Itoi E, Roach HI: Improved quantification of DNA methylation using methylation-sensitive restriction enzymes and real-time PCR. Epigenetics 2007, 2(2):86-91. 
43. Laird P: Principles and challenges of genomewide DNA methylation analysis. Nat Rev Genet 2010, 11(3):191-203.

44. Schumacher A, Kapranov P, Kaminsky Z, Flanagan J, Assadzadeh A, Yau P, Virtanen C, Winegarden N, Cheng J, Gingeras T, Petronis A: Microarray-based DNA methylation profiling: technology and applications. Nucleic Acids 2006, 34(2):528-542.

45. Cross SH, Charlton JA, Nan X, Bird AP: Purification of CpG islands using a methylated DNA binding column. Nat Genet 1994, 6(3):236-244.

46. Rauch T, Li H, Wu X, Pfeifer GP: MIRA-assisted microarray analysis, a New technology for the determination of DNA methylation patterns, identifies frequent methylation of homeodomain-containing genes in lung cancer cells. Cancer Res 2006, 66(16):7939-7947.

47. Jones PA: Functions of DNA methylation: islands, start sites, gene bodies and beyond. Nat Rev Genet 2012, 13(7):484-492.

48. Zilberman D, Henikoff S: Genome-wide analysis of DNA methylation patterns. Development 2007, 134(22):3959-3965.

49. Smith Z, Chan M, Mikkelsen T, Gu H, Gnirke A, Regev A, Meissner A: A unique regulatory phase of DNA methylation in the early mammalian embryo. Nature 2012, 484(7394):339-344.

50. Smallwood SA, Tomizawa S, Krueger F, Ruf N, Carli N, Segonds-Pichon A Sato S, Hata K, Andrews SR, Kelsey G: Dynamic CpG island methylation landscape in oocytes and preimplantation embryos. Nat Genet 2011, 43(8):811-814

51. Harris RA, Wang T, Coarfa C, Nagarajan RP, Hong C, Downey SL, Johnson BE, Fouse SD, Delaney A, Zhao Y, Olshen A, Ballinger T, Zhou X, Forsberg KJ, Gu J, Echipare L, O'Geen H, Lister R, Pelizzola M, Xi Y, Epstein CB, Bernstein BE, Hawkins RD, Ren B, Chung WY, Gu H, Bock C, Gnirke A, Zhang MQ, Haussler D, et al: Comparison of sequencing-based methods to profile DNA methylation and identification of monoallelic epigenetic modifications. Nat Biotechnol 2010, 28(10):1097-1105.

52. Fouse SD, Nagarajan RO, Costello JF: Genome-scale DNA methylation analysis. Epigenomics 2010, 2(1):105-117.

53. Michels KB, Binder AM, Dedeurwaerder S, Epstein CB, Greally JM, Gut I, Houseman EA, Izzi B, Kelsey KT, Meissner A, Milosavljevic A, Siegmund KD, Bock C, rrizarry RA: Recommendations for the design and analysis of epigenome-wide association studies. Nat Methods 2013, 10(10):949-955.

54. Gu H, Bock C, Mikkelsen TS, Jager N, Smith ZD, Tomazou E, Gnirke A, Lander ES, Meissner A: Genome-scale DNA methylation mapping of clinical samples at single-nucleotide resolution. Nat Methods 2010, 7(2):133-136.

55. Meissner A, Mikkelsen TS, Gu H, Wernig M, Hanna J, Sivachenko A, Zhang X, Bernstein BE, Nusbaum C, Jaffe DB, Gnirke A, Jaenisch R, Lander ES: Genome-scale DNA methylation maps of pluripotent and differentiated cells. Nature 2008, 454(7205):766-770.

56. Weber M, Hellmann I, Stadler MB, Ramos L, Paabo S, Rebhan M, Schubeler D: Distribution, silencing potential and evolutionary impact of promoter DNA methylation in the human genome. Nat Genet 2007, 39(4):457-466.

57. Elango $\mathrm{N}, \mathrm{Yi} \mathrm{SV}$ : Functional relevance of $\mathrm{CpG}$ island length for regulation of gene expression. Genetics 2011, 187(4):1077-1083.

58. Krausz C, Sandoval J, Sayols S, Chianese C, Giachini C, Heyn H, Esteller M: Novel insights into DNA methylation features in spermatozoa: stability and peculiarities. PLoS One 2012, 7(10):e44479.

59. Doi A, Park IH, Wen B, Murakami P, Aryee MJ, Irizarry R, Herb B, Ladd-Acosta C, Rho J, Loewer S, Miller J, Schlaeger T, Daley GQ, Feinberg AP: Differential methylation of tissue- and cancer-specific CpG island shores distinguishes human induced pluripotent stem cells, embryonic stem cells and fibroblasts. Nat Genet 2009, 41(12):1350-1353.

60. Bock C, Beerman I, Lien WH, Smith ZD, Gu H, Boyle P, Gnirke A, Fuchs E, Rossi DJ, Meissner A: DNA methylation dynamics during in vivo differentiation of blood and skin stem cells. Mol Cell 2012, 47(4):633-647.

61. Dean W, Santos F, Stojkovic M, Zakhartchenko V, Walter J, Wolf E, Reik W: Conservation of methylation reprogramming in mammalian development: Aberrant reprogramming in cloned embryos. Proc Natl Acad Sci 2001, 98(24):13734-13738.

62. Andersen I, Reiner A, Aanes H, Alestrom P, Collas P: Developmental features of DNA methylation during activation of the embryonic zebrafish genome. Genome Biol 2012, 13(7):R65.

63. Bui LC, Evsikov AV, Khan DR, Archilla C, Peynot N, Hénaut A, Le Bourhis D, Vignon $X$, Renard JP, Duranthon V: Retrotransposon expression as a defining event of genome reprograming in fertilized and cloned bovine embryos. Reproduction 2009, 138(2):289-299.
64. Peaston AE, Evsikov AV, Graber JH, de Vries WN, Holbrook AE, Solter D, Knowles BB: Retrotransposons regulate host genes in mouse oocytes and preimplantation embryos. Dev Cell 2004, 7(4):597-606.

65. Kigami D, Minami N, Takayama H, Imai H: MuERV-L is one of the earliest transcribed genes in mouse one-cell embryos. Biol Reprod 2003, 68(2):651-654

66. Kim M, Park Y-K, Kang T-W, Lee S-H, Rhee Y-H, Park J-L, Kim HJ, Lee D, Lee D, Kim S-Y, Kim YS: Dynamic changes in DNA methylation and hydroxymethylation when hES cells undergo differentiation toward a neuronal lineage. Hum Mol Genet 2013, 23(3):657-667.

67. Smyth GK, Michaud J, Scott HS: Use of within-array replicate spots for assessing differential expression in microarray experiments. Bioinformatics 2005, 21(9):2067-2075.

68. MCCarthy DJ, Smyth GK: Testing significance relative to a fold-change threshold is a TREAT. Bioinformatics 2009, 25(6):765-771.

69. Culhane AC, Thioulouse J, Perriere G, Higgins DG: MADE4: an R package for multivariate analysis of gene expression data. Bioinformatics 2005, 21(11):2789-2790.

70. Jurka J, Kapitonov W, Pavlicek A, Klonowski P, Kohany O, Walichiewicz J: Repbase Update, a database of eukaryotic repetitive elements. Cytogenet Genome Res 2005, 110(1-4):462-467.

71. Krzywinski M, Schein J, Birol I, Connors J, Gascoyne R, Horsman D, Jones SJ, Marra MA: Circos: an information aesthetic for comparative genomics. Genome Res 2009, 19(9):1639-1645.

72. Meyer LR, Zweig AS, Hinrichs AS, Karolchik D, Kuhn RM, Wong M, Sloan CA, Rosenbloom KR, Roe G, Rhead B, Raney BJ, Pohl A, Malladi VS, Li CH, Lee BT, Learned K, Kirkup V, Hsu F, Heitner S, Harte RA, Haeussler M, Guruvadoo L, Goldman M, Giardine BM, Fujita PA, Dreszer TR, Diekhans M, Cline MS, Clawson H, Barber GP, et al: The UCSC Genome Browser database: extensions and updates 2013. Nucleic Acids Res 2013, 41(D1):D64-D69.

73. O'Doherty AM, O'Shea LC, Fair T: Bovine DNA methylation imprints are established in an oocyte size-specific manner, which are coordinated with the expression of the DNMT3 family proteins. Biol Reprod 2012 86(3):67.

74. Tost J, Gut IG: DNA methylation analysis by pyrosequencing. Nat Protoc 2007, 2(9):2265-2275

doi:10.1186/1471-2164-15-451

Cite this article as: Shojaei Saadi et al: An integrated platform for bovine DNA methylome analysis suitable for small samples. BMC Genomics 2014 15:451.

\section{Submit your next manuscript to BioMed Central and take full advantage of:}

- Convenient online submission

- Thorough peer review

- No space constraints or color figure charges

- Immediate publication on acceptance

- Inclusion in PubMed, CAS, Scopus and Google Scholar

- Research which is freely available for redistribution 